\title{
Labor Market Distortions in Côte d'Ivoire: Analyses of Employer-Employee Data from the Manufacturing Sector
}

\author{
Nicolai Kristensen* \\ and \\ Dorte Verner* \\ World Bank \\ 1818 H St, NW \\ Washington, D.C. 20433 \\ U.S.A. \\ dverner@worldbank.org
}

\begin{abstract}
This paper investigates the extent and nature of distortions in the labor market in the Republic of Côte d'Ivoire (RCI) by using quantile regression analysis on employer-employee data from the manufacturing sector. We found that the labor markets in Côte d'Ivoire do not seem to be much distorted. Unions may influence employment through tenure but do not seem to influence wages directly except for vulnerable minorities that seem protected by unions. Establishment-size wage effects are pronounced and highest for white-collar workers. This may be explained by the efficiency wage theory, so that, even in the absence of unions, segmentation and inefficiencies will still be present as long as firms seek to retain their employees by paying wages above the market clearing level. The inefficiency arising from establishment-size wage effects can be mitigated by education. Furthermore, the premium to education is found highly significantly positive only for higher education, and not for basic education, indicating that educational policies should also focus on higher education.
\end{abstract}

\section{World Bank Policy Research Working Paper 3771, November 2005}

The Policy Research Working Paper Series disseminates the findings of work in progress to encourage the exchange of ideas about development issues. An objective of the series is to get the findings out quickly, even if the presentations are less than fully polished. The papers carry the names of the authors and should be cited accordingly. The findings, interpretations, and conclusions expressed in this paper are entirely those of the authors. They do not necessarily represent the view of the World Bank, its Executive Directors, or the countries they represent. Policy Research Working Papers are available online at http://econ.worldbank.org.

\footnotetext{
*We wish to thank colleagues from the Africa regional labor market study, Niels-Hugo Blunch, Wendy V. Cunningham, and Norbert M. Fiess, for their helpful comments and suggestions; and Eliana Cardoso, Helena Ribe, and Arvil van Adams for their invaluable support.
} 


\section{Introduction}

The lack of labor demand is the main problem in Sub-Saharan Africa (SSA), while labor supply is not a big problem. This consideration along with recent adverse terms of trade movements for SSA key export products call for flexibility of labor markets.

The labor market in Côte d'Ivoire has been deregulated but few studies analyze the possible existence of labor market distortions both before and after the start of reforms. ${ }^{1}$ Rama (1998) analyzes wage misalignment in RCI. He concludes that minimum wages are no source of distortion in the Ivorian labor market; real minimum wages in 1996 accounted for only about 35 percent of their level 20 years earlier. ${ }^{2}$

In this study we focus on two possible sources of labor market distortions in Côte d'Ivoire in the mid-late 1990s. First, we investigate the possible effects of unions on the individual income generation in the private manufacturing sector. Even though this sector involves only a small part of the labor force, it still plays an important role since a large part of exports originates from this sector, and since any export commodity dispersion is likely to come from this sector. ${ }^{3}$ Second, we analyze the possible existence of efficiency wages arising from employer-size wage effects.

Furthermore, the paper aims at analyzing the characteristics of the small group of private manufacturing sector workers - who to some extent may be viewed as role models — and how they differ within and between occupational groups. This may have implications for educational policies, for example, and is an important complement to the household-based analysis by Verner (1999c), which found that union effects cannot be analyzed in the 1990s due to survey changes.

One reason for the lack of studies that look at union effects in RCI is that the topic can only be satisfactorily analyzed by firm level data. This paper presents one of the first studies of employer-employee data, the so-called Regional Program on Enterprise Development (RPED) data set on Côte d'Ivoire from 1995 and 1996. This type of data represents a clear advantage to prior studies of the labor market, which rely on household surveys that are rather sparse on

\footnotetext{
${ }^{1}$ Appendix E contains an overview of labor market studies in RCI that makes use of regression techniques, based on individual data, to analyze wage/income generation.

${ }^{2}$ This drop is in line with market average wages which fell 60 percent in the 1985-95 period (Verner, 1999).

${ }^{3}$ Rama (1998) quotes ILO numbers, estimating 300,000 individuals as being union members in 1995 out of a total labor force of 7,063,000, which is equivalent to 4.25 percent of the entire labor force. These numbers are only estimates and highly uncertain.
} 
information about firms. Likewise, the data at hand proves superior to macro or aggregate data since the latter do not allow for direct linking of employers and employees.

The analysis is carried out using quantile regression techniques, which allow a more indepth characterization of individuals across the entire wage distribution, than does the more standard technique of Ordinary Least Squares (OLS).

The paper is organized as follows. Section 2 gives a brief overview of the Ivorian economy in the late 1990s. Section 3 outlines the economic model and explains the basic principles behind quantile regressions. Section 4 describes the surveys and the variables. Section 5 discusses a number of descriptive statistics and section 6 presents analytical results from quantile regressions. Finally, section 7 concludes with a summary of findings and policy implications and recommendations.

\section{The Ivorian economy in the late $20^{\text {th }}$ century}

As many Sub-Sahara African countries, RCI experienced a very severe recession throughout the 1980s, triggered by a dramatic fall in export prices for key commodities such as cocoa, coffee, and oil. At the same time, the CFA was pegged to the French franc, and the latter appreciated substantially against the US dollar, resulting in a deterioration of competitiveness and a drop in exports from RCI. Furthermore, the 1980s were characterized by a labor market heavily restricted by rules and regulations. For instance, as reported by Rama (1998), the government had monopoly over hiring decisions. All vacancies had to be reported to central offices, which also were responsible for registering all job searchers and making all placements, despite a tendency for these offices to be highly inefficient. Firing costs were high, too, since workers fired for economic reasons often managed to obtain several yearly salaries due to the courts" assessment that firing was "abusive".

The 50 percent devaluation of the CFA in 1994 removed a major obstacle to economic adjustment in Côte d'Ivoire, and resulted in a major repatriation of flight capital from the early 1990s when the currency was overvalued. Afterwards, the economy has blossomed. Annual GDP growth has averaged more than 6 percent; investments almost doubled from 1993 to 1996; and the wage bill to GDP ratio declined by one third in the same period. The labor market was 
also included in the general drive towards more democracy. Competition in collective bargaining was introduced and the monopoly of hiring and firing decisions was abandoned. ${ }^{4}$

Sub-Sahara Africa, including RCI, experienced a dramatic fall in the prices of its key commodities. The prices in the late 1990s were the lowest in 30 years, and the outlook for longterm real prices is not favorable. Exports from RCI constitute 28 percent of GDP, which is relatively high for a Sub-Saharan country but far below the level obtained in RCI in the late 1970s. Furthermore, exports from RCI is highly concentrated with 46 percent of total exports to OECD in 1997 being in one single commodity, cocoa, which makes the economy highly vulnerable to price fluctuations. ${ }^{5}$

\section{Methodology}

\subsection{The economic model}

One could argue that wages and employment are determined jointly and hence constitute a system of equations to be estimated (Verner 1999a, b). But, Maloney and Ribeiro (1999) note that standard wage equations with employment omitted can be thought of as a reduced form and can be estimated using one-step estimators such as least squares or quantile regressions. Hence, the underlying economic model used in the analysis will simply follow Mincer's (1974) human capital earnings function extended to control for a number of other variables that relate to the firm. In particular, we apply a semi-logarithmic framework that has the form:

$$
\ln y_{i}=\varphi\left(x_{i}, z_{i}\right)+u_{i}
$$

where $\ln \mathrm{y}_{\mathrm{i}}$ is the $\log$ of earnings or wages for individual $i$; $\mathrm{x}_{\mathrm{i}}$ is a measure of a number of personal characteristics, including human capital variables, ethnicity, etc.; and $\mathrm{z}_{\mathrm{i}}$ represents firmspecific variables, for instance, profit per employee in the firm. The functional form is left unspecified in equation (1). We choose to make extensive use of dummy variables in order to catch non-linearities in returns to years of schooling, tenure, and other quantitative variables. The last component, $\mathrm{u}_{\mathrm{i}}$, is a random disturbance term that reflects unobserved characteristics.

\subsection{Quantile regressions}

\footnotetext{
${ }^{4}$ Verner (1999c) gives a more detailed historical description of the RCI economy.

${ }^{5}$ Source: UN Comtrade, World Bank (1998a, b).
} 
The method applied in this paper is quantile regression. The idea is that one can choose any quantile and thus obtain many different parameter estimates. In this manner the entire conditional distribution can be explored. By testing whether coefficients for a given variable across different quantiles are significantly different, one implicitly also tests for conditional heteroskedasticity across the wage distribution.

The method has many other virtues apart from being robust to heteroskedasticity. When the error term is non-normal, for instance, quantile regression estimators may be more efficient than least squares estimators. ${ }^{6}$ Furthermore, since the quantile regression objective function is a weighted sum of absolute deviations, one obtains a robust measure of location and, as a consequence, the estimated coefficient vector is not sensitive to outlier observations on the dependent variable. ${ }^{7}$

The main advantage, though, is the semi-parametric nature of the approach, which relaxes the restrictions on the parameters to be fixed across the entire distribution. Intuitively, quantile regression estimates convey information on wage differentials arising from nonobservable characteristics among individuals otherwise observationally equivalent. In other words, by using quantile regressions, we can determine if individuals that rank in different positions in the conditional distribution (i.e., individuals that have higher or lower wages than predicted by observable characteristics) receive different premiums to education, tenure, or to other relevant observable variables.

Labor market studies usually make use of conditional mean regression estimators, such as Ordinary Least Squares ${ }^{8}$. This technique is subject to criticism because of several, usually heroic assumptions underlying the approach. One is the assumption of heteroskedasticity in the distribution of the error terms. If the sample is not completely homogenous, this approach, by

\footnotetext{
${ }^{6}$ Ibid.

${ }^{7}$ That is, if $y_{i}-x_{i}^{\prime} \hat{\beta}_{\theta}>0$, then yi can be increased toward $+\infty$, or if $y_{i}-x_{i}^{\prime} \hat{\beta}_{\theta}<0$, yi can be decreased toward $-\infty$, without altering the solution $\hat{\beta}_{\theta}$. In other words, it is not the magnitude of the dependent variable that matters but on which side of the estimated hyperplane the observation is. This is most easily seen by considering the FOC to (3), which can be shown to be given as (see Buchinsky 1998) $\frac{1}{n} \sum_{i=1}^{n}\left(\theta-\frac{1}{2}+\frac{1}{2} \operatorname{sgn}\left(y_{i}-x_{i}^{\prime} \hat{\beta}_{\theta}\right)\right) x_{i}=0$.

This can be seen both as a strength and a weakness of the method. In the present context, with data from Côte d'Ivoire, the advantages seem to outweigh the disadvantages, since the reliability of data from LDCs generally is questionable. However, to the extent that a given outlier represents a feature of the "true" distribution of the population, one would prefer the estimator to be sensitive to such an outlier - at least to a certain degree.

${ }^{8}$ See Velenchik (1997) and Verner (1999a,b).
} 
forcing the parameters to be the same across the entire distribution of individuals may be too restrictive and may hide important information.

A simple solution and yet a powerful tool is to make use of quantile regression techniques. The method of quantile regression amounts to minimizing the absolute sum of errors rather than, as in least squares, minimizing the sum of their squares.

Formally the method, first developed by Koenker and Basset (1978), can be formulated as $^{9}$

$$
\mathrm{y}_{\mathrm{i}}=\mathrm{x}_{\mathrm{i}}^{\prime} \beta_{\theta}+\mathrm{u}_{\theta \mathrm{i}}=\operatorname{Quant}_{\theta}\left(\mathrm{y}_{\mathrm{i}} \mid \mathrm{x}_{\mathrm{i}}\right)=\mathrm{x}_{\mathrm{i}}^{\prime} \beta_{\theta}
$$

where Quant $\mathrm{\theta}_{\theta}\left(\mathrm{y}_{\mathrm{i}} \mid \mathrm{x}_{\mathrm{i}}\right)$ denotes the $\theta^{\text {th }}$ conditional quantile of $\mathrm{y}$ given $\mathrm{x}$, and $i$ denotes an index over all individuals, $i=1, \ldots, \mathrm{n}$.

In general, the $\theta^{\text {th }}$ sample quantile $(0<\theta<1)$ of y solves

$$
\min _{\beta}=\frac{1}{n}\left\{\sum_{i: y_{i} \geq x_{i}^{\prime} \beta} \theta\left|y_{i}-x_{i}^{\prime} \beta\right|+\sum_{i: y_{i}<x_{i}^{\prime} \beta}(1-\theta)\left|y_{i}-x_{i}^{\prime} \beta\right|\right\}
$$

Buchinsky (1995) examines various estimators for the asymptotic covariance matrix and concludes that the design matrix bootstrap performs the best. In this paper, the standard errors are obtained by bootstrapping using 200 repetitions, in line with the literature.

\section{Data description}

\subsection{The Surveys}

The data used in this study are drawn from surveys of manufacturing firms in Côte d'Ivoire conducted in 1995 and 1996. The surveys are part of the RPED, a multi-year study of the manufacturing sector in several African countries (Cameroon, Côte d'Ivoire, Ghana, Kenya, Rwanda, Burundi, Tanzania, Zambia, and Zimbabwe). The RPED was organized by the Africa Region Technical Department of the World Bank.

The RPED is designed to provide an overview of the performance of manufacturing firms in the post-structural adjustment period, and focuses on a wide variety of aspects of firm behavior. The survey instruments include several modules covering creation of the enterprise; the enterprise in general; interior competition; labor markets; financial markets; solutions to

\footnotetext{
${ }^{9}$ See Buchinsky (1998).
} 
conflicts; infrastructure; regulations; adjustments; investors; use of help from (public) institutions; employees; and apprentices.

In Côte d'Ivoire, data were collected for two successive years, covering 234 and 230 manufacturing enterprises in 1995 and 1996, respectively. A moving panel structure was applied, which implies that some of the firms surveyed in 1995 also were surveyed in 1996. Likewise, some workers surveyed in 1995 were also included in the sample in 1996. Problems of sample attrition and missing values for some key variables haunt the surveys and have seriously reduced the sample size, both in terms of number of observations and variables, requiring that we pool the two samples. By doing so, we implicitly assume that the relatively few firms (26) and workers (95) that are counted twice are no source of bias; that is, firms and workers present in both years do not, in any systematic fashion, deviate from firms and workers not present in both years. ${ }^{10}$ The wages of the pooled sample are deflated, using 1995 as the base year. The samples do not contain information on regional locality, presumably because the vast majority of firms are located in Abidjan. Hence, no regional or spatial deflation is feasible. To the extent that some firms are from outside Abidjan, results may lead to a downward bias in the salaries of workers employed in these firms.

Furthermore, women represent only 10 percent of the observations. This may mirror the true picture; but the sample is deemed too small for meaningful analysis of women, and these observations are, therefore, excluded from the analysis. Hence, both sample and any policy recommendations are limited to male workers employed in the manufacturing sector. The number of observations is 891 males that work in 128 different manufacturing enterprises. ${ }^{11}$

Despite the abovementioned problems, the data set remains highly interesting, since it is among the first data collected on manufacturing enterprises in Côte d'Ivoire. For the selected group consisting of male workers employed in the manufacturing sector, we are able to perform meaningful analysis despite the limitations discussed above.

\footnotetext{
${ }^{10}$ In the regression analysis, we include a dummy that equals 1 if the year is 1996 and zero otherwise. This dummy almost always turns out to be significant. Our interpretation is that, while the samples may differ, none can, a priori, be said to be more representative of the "true" population. Pooling the samples can perhaps average out any nonrepresentativeness, resulting in a pooled sample that may even be more representative.

${ }^{11}$ Ideally, one would take into account the potential (self)-selection taking place here, and estimate, e.g., a selection model in the vein of Heckman (1979) and others. However, it is increasingly recognized that this method requires assumptions that are not likely to hold. For instance, assumptions on what is determining the selection mechanism has to be made, and the results in the wage-equation are often very sensitive to these assumptions. Therefore, we choose not to apply any selection method. Given that we only study males, the issue of self-selection may be less of a problem as compared to biases, had the analysis included females, where selection tends to be most prevalent.
} 


\subsection{Variables}

Dependent variable:

We use wages as our dependent variable. Throughout the paper, these are calculated and reported as real monthly wages. In the quantile regressions, the dependent variable is the natural log of monthly wages. ${ }^{12}$

Explanatory variables:

Age dummies: yrgroup1 includes all workers aged 15-25; yrgroup2 includes workers aged 26-45 years; and yrgroup3 includes workers aged 46-65. These variables proxy for general experience (firm-specific experience is captured by tenure (see below)).

Educational dummies: edunone includes all workers with no education; edubasic includes workers who have obtained primary or secondary education diplomas; and eduhigh includes workers who have obtained a higher degree than secondary diploma.

Union variables: Two union variables are included in the analysis. The first variable union takes on the value of 1 if the worker himself indicates he is a union member, and zero otherwise. The second variable density is a proxy for the degree of unionization in each establishment. It is constructed as the ratio of interviewed workers in a given firm that state they are members of a union relative to all interviewed workers in the firm.

Tenure dummies: tenure 1 is a dummy variable that takes on the value of 1 if tenure in the current job is 0-5 years and zero otherwise; tenure 2 equals 1 if tenure in current job is 6-12 years and zero otherwise; and tenure 3 equals 1 if tenure is longer than 12 years and zero otherwise.

Occupational dummies: The workers are split into 5 different categories: manager includes management, supervisors, and foremen; admsales includes administration and sales personnel; techmain includes technicians and maintenance; qprod includes qualified production workers; and support is a dummy variable for support staff.

Industrial dummies: The workers are split into 5 broad industrial categories, which are textile, food, wood, metal, and a group with "other industry" or "industry not stated" called otherin.

\footnotetext{
${ }^{12}$ Any measure of in-kind benefits is not part of this variable and is not included in the analysis. Admittedly, these may be important but there are too many missing values for them to be included.
} 
Firm size: The number of employees in each firm was split into 4 groups: microf includes firms with less than 17 employees; smallf includes firms with 17-40 employees; mediumf includes firms with 41-99 employees; and largef includes firms with 100 or more employees. Furthermore, we constructed a variable, firm40, which takes on the value of 1 if the number of employees in the firm is 40 or more, and zero otherwise.

Other variables: We include a dummy variable for nationality/ethnicity, Ivorian, that equals 1 if the worker's nationality is Ivorian and zero otherwise; a dummy variable for the nationality of the owner, franlib, that takes on the value of 1 if there is a majority of French or Lebanese owners and zero otherwise. Finally, we include a variable, profitper, to measure profit per employee in each firm.

\section{Descriptive statistics}

A little more than half of the workers included in the sample are trade union members (table A1 in appendix A). Not surprisingly, larger firms tend to be more unionized than smaller firms. About 72 percent of the men working in a firm with 40 employees or more report union membership, while the corresponding number for firms with less than 40 employees is 31 percent. Since 57 percent of the firms with 40 or more employees are owned by a majority of either French or Lebanese stockholders, naturally the same picture emerges when one looks at unionization across ownership. Sixty-seven percent of the workers in French/Lebanese owned firms are in a union as compared to 43 percent of the workers in firms not owned by a majority of French/Lebanese stockholders. However, the causality between rate of unionization, size of firm, and nationality of ownership is not clear.

Workers with no education (edunone) are less prone to be organized than workers with basic education, and even less prone than workers with high education (42 percent, 63 percent, and 52 percent, respectively). Occupational groups such as managers, administrative and sales personnel, technicians, and maintenance staff are relatively more often members of a union than are qualified production workers and, especially, than are support personnel.

Almost half of the workers report tenure of less than 6 years in the firm where they are currently working, while the rest are equally distributed in the '6-12' and 'more than 12' years of tenure brackets. Tenure is generally much longer in French/Lebanese owned firms. These firms 
also tend to have more educated workers, so again there is an issue of causality. ${ }^{13}$ French/Lebanese-owned enterprises are not so active in the food, wood, or textile industries, but are mainly operating in the metal industry (47 percent).

Very few of the workers ( 6 percent) report they have received training after entering the firm (in the form of either on-the-job training or training outside the enterprise). With so few observations, it is very hard to generalize these findings. However, it seems as if firms with more than 40 employees are undertaking more training (9 percent) than smaller firms (2 percent)-corresponding to more training in firms with the higher educated workforce. Presumably, the higher the education the more "trainable" is the individual and, hence, the return to training increases with the level of education. The data do support this hypothesis (table A4), but the number of observations is very low.

The monthly real wages for the three different tenure groups are surprisingly closely distributed (see figure A1), whereas the three educational groups are widely dispersed. Highly educated workers earn much higher wages than workers with no education or only basic education. The earnings of highly educated workers are also very heterogeneous within the group, but they vary much more across the percentiles than do the wages for the other two educational groups. The graph also indicates that wages of workers that are union members may be a little more homogeneous than wages of non-union members, since their wage curve is slightly more flat across the percentiles. This corresponds to the calculations of decile ratios given in table A5. This indicates that in the upper part of the distribution $\left(50^{\text {th }}\right.$ to $\left.90^{\text {th }}\right)$, union and non-union member wage distributions differs the most. In the low end $\left(10^{\text {th }}\right.$ to $\left.50^{\text {th }}\right)$, the ratio $50^{\text {th }} / 10^{\text {th }}$ is almost the same for the 2 groups (union $=1.96$; nonunion $=2.14$ ), while the $90^{\text {th }} / 50^{\text {th }}$ ratio differs more (union $=2.45$; nonunion $=4.60$ ).

Finally, the firm size seems to influence the level of the wage distribution. Large firms pay higher wages (figure A1), but there is less inequality within each group of firm size. The inequality is almost identical within the two groups of firms (table A5).

\footnotetext{
${ }^{13}$ Is the tenure longer because French/Lebanese firms treat their employees differently/better or because they hire more educated staff and tenure is positively related to the level of education? The data do not support the last hypothesis: eduhigh generally has a lower tenure related to it than does edubasic/edunone (see table A4). One should not put too much emphasis on these very partial descriptions, though.
} 


\section{Analytical results}

\subsection{General results}

Table B1 presents the quantile regression results and, as a reference, OLS results. Estimates for the $10^{\text {th }}, 25^{\text {th }}, 50^{\text {th }}, 75^{\text {th }}$, and $90^{\text {th }}$ quantiles are presented to identify differences between low earners and high earners conditional on observables. Most of the variables enter with the expected sign at all quantiles. In the following, each variable's impact on wages is discussed.

Age and tenure. Both age dummies yrgroup2 and yrgroup3 are positive and highly statistically significant at all quantiles $\left(10^{\text {th }}, 25^{\text {th }}, 50^{\text {th }}, 75^{\text {th }}\right.$, and $\left.90^{\text {th }}\right)$, hence, impacting wages in RCI positively. The age dummies proxy for general, as opposed to firm-specific experience. The regressions show that workers with general experience receive a premium, and the premium increases with increased skill level. Tenure is also positive and the estimated coefficients are non-constant as they increase with tenure. Tenure over 12 years (tenure3) is significant for all quantiles, while 6-12 years of tenure (tenure2) is highly insignificant in the upper quantiles $\left(75^{\text {th }}\right.$ and $\left.90^{\text {th }}\right)$. At the $90^{\text {th }}$ quantile, the coefficient even becomes negative, though it is statistically insignificant. One would expect tenure to have a positive effect on wages as it captures a pay-off to experience. In Côte d'Ivoire this pay-off does not seem to be systematic and, therefore, possibly delinks experience from wages. ${ }^{14}$

Education. Completed basic education with diploma generally enters with the expected positive sign but is statistically insignificant at all quantiles (with respect to no completed education). This may be explained by the fact that we only analyze wages in the manufacturing sector (see more below). Completed higher education relative to no completed education is positive and significantly different from zero at the 1 percent level across all quantiles. The premium obtained by highly educated workers ranges between 33 percent $\left(10^{\text {th }}\right)$ and 105 percent $\left(90^{\text {th }}\right)$, and increases almost linearly with the quantile, vis-à-vis workers with no education. ${ }^{15}$

Why is there not a premium to basic education as compared to no completed educationa result that strongly differs from prior expectations and from previous results in the literature (see survey-table in appendix E)? In Verner (1999c) the return to basic education is generally found significant and positive. When restricting the 1995 sample to males only (as we have

\footnotetext{
${ }^{14}$ The result is robust to different splines. In particular, introducing a dummy for 0-1 years of tenure and a dummy for 2-5 years of tenure along with tenure 2 and tenure 3 does not change the result.
} 
here), Verner also gets an insignificant return to basic education at the $10^{\text {th }}$ and $25^{\text {th }}$ quantiles. This could be a sign of a 'structural' shift in the wage setting since the return to basic education in the 1980 s is found to be statistically significant. One explanation could also be that our sample is highly selective: we do not look at the population as a whole but only at those privileged males employed in the manufacturing sector. This selection may be more pronounced for individuals with no education since, relatively, these individuals are less prone to be in the manufacturing sector. An analysis of the entire population could result in a significant impact on wages from having completed basic education. ${ }^{16}$

It is worth noticing that basic education impacts wages significantly in the OLS regression and, hence, analysis based on this method would have given an entirely different conclusion.

Our interpretation of the finding is that education is important for the individual wage formation, but that basic level education (primary and secondary diplomas) is not enough to affect the wage setting process. It may serve as a screening device in the hiring process. For education to have a significant impact on wages in the manufacturing sector, a higher level of education is required.

Employer size effects. There is a very significant positive premium to being employed in large firms - the group of comparison is firms with less than 17 employees (microf). The relationship is not linear since firms with 17-40 employees (smallf) get a higher premium than firms with 41-99 employees (mediumf). This employer-size wage effect may arise from simple market based factors and merely be a sign of an efficient market. It could, however, also be a sign of inefficiency - through efficiency wages, if it is not warranted by inferior working conditions or other factors. This issue will be taken up in section 5.3.

Industrial sectors. The industry dummies are generally insignificant except for the metal industry, where employees receive a wage premium ranging between 15.2 percent $\left(25^{\text {th }}\right)$ to 35.1 percent $\left(10^{\text {th }}\right)$ vis-à-vis the textile industry. The metal industry is primarily run by French/Lebanese owners but this is already controlled for in the regression - the dummy variable for French/Lebanese ownership (franlib) is also positive and highly significant.

\footnotetext{
${ }^{15}$ To obtain these premiums, one has to calculate (exp (coefficient estimate) -1$) * 100$.

${ }^{16}$ Theoretically, another possibility is that school quality could have fallen. We have no information on this issue.
} 
Union. When all the abovementioned factors are taken into account, the union membership variable becomes statistically insignificant at all quantiles. Hence, unions do not appear to have any measurable impact on workers' wages. One exception is the $75^{\text {th }}$ quantile, where union membership impact wages significantly negatively. The "return" to union membership at the $75^{\text {th }}$ quantile is -13 percent. ${ }^{17}$ This finding would be highly surprising for an analysis of labor markets in any OECD country. For an LDC, it is less surprising due to the high level of underemployment, and our finding is also in line with the findings of several other studies. ${ }^{18}$ An interpretation of the finding is that workers who earn a relatively high wage (that is, are at the $75^{\text {th }}$ quantile), given measured characteristics, are "punished" by the unions. Assume a worker with non-observable characteristics, such as motivation and reliability that are very "good". He ought to be paid a higher wage than other workers with the same observable characteristics; but union membership will push him down the wage ladder towards the average. It could also be an indication of a social awareness among the union member workers in the $75^{\text {th }}$ quantile, since they accept the unions' negative impact on their wage outcome-maybe in order to help secure the firms' competitiveness and their own future employment in a world of rapid technological change. This interpretation points to a very different, more positive effect stemming from unions than they are normally attributed in the literature, which mainly focuses on OECD countries.

In the theoretical literature on unions, it has long been recognized that unions may influence factors other than wages such as, for example, security in employment (tenure) or less variation in wages. Still, a negative coefficient is unexpected. Maloney and Rebeiro (1999) obtain similar results for the impact of union density on skilled-worker wages in Mexico. They argue it could be due to more successful bargaining over firm rents by unskilled workers (received in forms other than wages), or that it is related to a desire to reduce the wedge between skilled and unskilled remuneration for equity reasons. Such equity considerations may also apply here. The issue of union influence and power will be further analyzed in the next section.

Occupation. The occupational variables turn out to be highly significant for all occupational groups and for all quantiles. The reference group is support staff. The wage premium to manager as compared to support staff increases over the quantiles from 100 percent

\footnotetext{
${ }^{17}$ Substituting union membership with union density in the model specification, following the assumption that the union power depends on this, does not in any way alter the above results.
} 
$\left(10^{\text {th }}\right)$ to 200 percent $\left(90^{\text {th }}\right)$. Not surprisingly, the premium decreases as one goes down in the "worker hierarchy." The technician/maintenance group receives premiums ranging from 43 percent $\left(10^{\text {th }}\right)$ to 110 percent $\left(90^{\text {th }}\right)$; the administration/sales group receives a premium of some 26 percent $\left(10^{\text {th }}\right)$ up to 96 percent $\left(90^{\text {th }}\right)$; and finally the qualified production workers receive premiums ranging from 7 percent $\left(25^{\text {th }}\right)$ to 22 percent $\left(90^{\text {th }}\right)$. Generally, these numbers do only reveal substantial between-group heterogeneity; they also suggest extreme within-group heterogeneity across the distribution of male manufacturing workers. The within (occupational) group heterogeneity is largest in the top of the "hierarchy" and decreases gradually. ${ }^{19}$

The same pattern of increasing premiums over the quantile-level is found for education: highly educated workers are much more heterogeneous than basic educated workers. This is illustrated graphically for both education and occupation in figure B1, where 90 percent confidence limits also are given. The figure suggests that not only are the coefficients changing across the distribution but the changes also seem to be statistically significant. Indeed, simple one-sided t-tests confirm that coefficients change for occupational groups and higher education and that these changes generally are significant at the 1 percent level (table B2). The standard regression techniques (OLS and 2SLS) hide many insights that are statistically important. In the same vein, the t-tests show that for almost all variables there is too much heterogeneity to restrict the coefficient of a variable to be the same across the entire wage distribution.

\subsection{Separate analysis of union and non-union members}

In the following, we split the worker sample into two groups: unionized and nonunionized. We split the sample to analyze if unions cause wage differentials or if they are more prone to be present in certain firms that also happen to pay higher (or lower, if the estimated coefficient to union is statistically significant and negative) wages.

In the quantile regressions including all observations, tenure 2 is insignificantly different from zero (table B1). When the samples are split into unions being present at the workplace versus unions not being present, the tenure2-coefficient becomes significantly different from zero across quantiles in the union sample and remains insignificant in the non-union sample (table $\mathrm{C} 1$ ). Therefore, constraining the tenure 2 coefficient to be equal for both sub-groups could

\footnotetext{
${ }^{18}$ See Verner (1999a) and Rama (1998).
} 
give rise to differences in the union coefficient. The differing tenure 2 coefficient estimates may indicate, for example, union power that leads to wage promotions according to tenure. ${ }^{20}$ The problem sketched here is one of selection bias in measuring the union premium, which perhaps can be mitigated by including the density variable in the union regressions. Recall that density measures the share of workers interviewed at a given work plant that are union members, over all workers interviewed at the plant. This variable is used as a proxy for unionization in the entire enterprise.

A Mann-Whitney test for equality of sub-populations (workers in unionized firms are equal to workers in non-unionized firms) strongly rejects equality at the 1 percent level, which also suggests that union and non-union workers may be fundamentally different. ${ }^{21}$

On these grounds the sample was split into the two sub-samples: one for workers from firms where part of the workforce are union members - that is, where density is different from zero; and one for workers from firms with no union members - that is, where density is equal to zero.

A number of insights are obtained by splitting the samples by unionized firms (table C1). The coefficient to the indicator variable for Ivorians shows that Ivorians earn a much higher income at the lower quantiles than non-Ivorians, conditional on workers that are employed in non-unionized enterprises. The premium to Ivorians is as high as 52 percent at the $25^{\text {th }}$ quantile. In enterprises with some degree of unionization, Ivorian is insignificant except at the top quantiles $\left(75^{\text {th }}\right.$ and $\left.90^{\text {th }}\right)$ where it becomes statistically significant and negative. This suggests that union-membership or union presence at a work-site protects non-Ivorian workers from wage discrimination. Then, non-Ivorian workers who earn low wages (given other measured characteristics) - maybe, perhaps, due to a low degree of motivation, reliability, or other unobservable characteristics - are, therefore, pushed by non-Ivorian unions towards the average income class. Undoubtedly, this group is primarily (if not solely) comprised of other African

\footnotetext{
${ }^{19}$ Manager includes both management, supervisors, and foremen. However, if one looks at management only, the heterogeneity still prevails.

${ }^{20}$ See Borjas (1996). Maloney and Ribeiro (1999) find similar results for Mexico.

${ }^{21}$ Given the low number of observations, we face some limitations. Therefore, in what follows, we concentrate on robust results.
} 
nationalities and does not include, say, French citizens. This group probably belongs in the top of the distribution that leads to the reverse in the sign. ${ }^{22}$

Just as union was insignificant when all workers were included in the regressions, density turns out insignificant here, except at the $90^{\text {th }}$ quantile where it is significantly negative. This hardly suggests any union power in the wage bargaining process - a surprising result that supports our previous findings in section 5.1. Union power can, as mentioned in the last section, have different shades. If it does not affect wages directly, maybe it has power along various other dimensions - one of them seemed to be to protect non-Ivorians in the lower end of the wage distribution as we discussed previously. Other channels may be tenure, profit per employee, or occupational group, each of which we will consider in turn in the following.

Tenure: As mentioned in the introduction to this section, with respect to 0-5 years of tenure, we find 6-12 years of tenure (tenure2) to be statistically significant (at least at the 10-15 percent significance level) for the $10^{\text {th }}-50^{\text {th }}$ quantiles in the regressions for unionized firms and generally insignificant and/or with lower premium in the non-unionized firm regressions. This may suggest that career paths in the unionized world are more rigid, following rules of promotion and wage increases that are based on tenure and not so much individual performance. However, the story could also simply be that certain enterprises tend to train their employees more, and the same enterprises happen to have some degree of unionization. Neither story can be ruled out. Whether unionized firms train their workers more than non-unionized firms is difficult to tell given the low number of workers who have received training. However, as table A1 suggests, this may be the case.

Profit per employee: In the unionized firm regressions, the profit per employee is significantly positive across the entire distribution (the coefficient is very low though, about 1.1E-08), while it is insignificant across the entire distribution for non-unionized firms. This indicates that union power leads to profit-sharing, and thus, indirectly, unions may affect wages.

Occupation: The occupational groups have a vast impact on wages in the unionized firms, while they generally have a much smaller and often insignificant impact on wages in nonunionized firms. A priori, one would expect such a pattern, and it may be taken as evidence of union power that results in more rigid wage patterns between groups. Thus, the between-

\footnotetext{
${ }^{22}$ No quantile regressions were run with the three groups - Ivorians, other Africans, and other nationalities - since this would lead to too few observations in certain brackets.
} 
(occupational)-group heterogeneity seems to originate, at least partly, from the presence of unions, and it shows the result of the detailed grid wage bargaining that takes place in RCI.

What about the within-(occupational)-group heterogeneity? One would expect it to be less pronounced in the unionized enterprises since unions tend to average out differences. This does not seem to be the case here, though, as becomes evident when looking at the distribution of coefficients across quantiles for each occupational group (figure $\mathrm{C} 1$ ). The occupational coefficients vary much more across quantiles for workers in unionized enterprises than they do for workers in non-unionized enterprises, which indicate a higher degree of within-group heterogeneity. Not only are the coefficients higher and more significant for workers in unionized enterprises, they also vary much more. This is surprising, and does not conform to a high degree of union power.

\subsection{Establishment-size effects}

The preceding paragraph suggests that union power particularly affect tenure. In the literature, tenure has also been associated with establishment-size premiums; that is, that larger firms pay higher wages to their workers as compared to observationally equivalent workers in smaller establishments. ${ }^{23}$ The question here is whether unions succeed in negotiating a higher job security, which results in longer tenure, or whether the long tenure arises because large establishments pay relatively higher wages, which results in a low turn-over rate? Unfortunately, this cannot be analyzed in depth by the data at hand.

That establishment-size effects may play a very large role in Côte d'Ivoire seems likely given our previous results that suggest intrinsic differences between small and large firms. A Mann-Whitney test for whether the individual earnings for workers employed in firms with less than 40 employees are equal to firms with 40 employees or more, strongly rejects the hypothesis of equality. On this basis, we split up the sample once more. ${ }^{24}$ The results so far (section 6.1) show a non-linear relationship in firm-size premiums where small firms (17-40 employees) at some quantiles receive a greater size-premium than medium size firms (41-99 employees). That

\footnotetext{
${ }^{23}$ For LDCs see Schaffner (1998) and Velenchik (1997).

${ }^{24}$ An alternative would be to simply include interaction-effects between variables. Since this, however, would not lend the same flexibility for all coefficients to vary (except if interaction terms are included for every single variable), we choose not to do that.
} 
we choose to cut the sample at firm size 40 is, therefore, based more on considerations related to equal size of sub-samples since we have relatively few observations.

The results indicate that, indeed, tenure may be strongly related to establishment-size effects (see table D1). Tenure is more often significant and generally receives a higher premium in large firms (40 or more employees) after controlling for union density. Thus, it could be that unions just happen to be more present in large establishments and that these pay an employersize wage effect that lead to a lower degree of turn-over.

Union density enters significantly positive in the small-establishment regressions at the lower quantiles $\left(10^{\text {th }}\right.$ and $\left.25^{\text {th }}\right)$, while it enters significantly negative at the upper quantiles in the large-establishment regressions. The first result corresponds to what one would expect and indicates that unions protect the low-income workers who, given measured human capital and other variables, are in the low end of the income distribution. These workers are pushed upwards by the union. For the upper quantiles, though, why would anybody be a union member if the pay-off is negative? An explanation could be that job security increases, which also partly may explain the difference between tenure premiums in large vs. small firms, since large firms tend to be more unionized.

Why does the employer size-wage effect occur? A number of explanations have been discussed in the literature. It could simply be an efficient market-determined pay-back to inferior working conditions. Why, then, should working conditions be more inferior in large establishments? One explanation is that larger firms may have to hire workers from a geographically broader area, which will increase commuting costs. Unfortunately, we do not have data to control for this. However, it seems highly unlikely that this should be the whole story. $^{25}$

The market-based explanation of the employer-size wage effect is probably not enough. Other economic explanations include problems and costs associated with monitoring shirking, hiring costs, and costs connected with the screening of applicants combined with the need for high quality workers. Non-economic explanations have also been launched. A sociological explanation is that an excessive wage will increase the morale and will be viewed as a gift that must be paid back. A political explanation argues that large firms want to maintain some 
monopoly power and be on good footing with local government representatives. Of these possible explanations, the shirking and/or turnover explanations may be the most promising, but why should these costs increase with firm size? Higher capital-labor ratios, more sophisticated technology, higher ratios of workers to owners, and deeper hierarchies in larger establishments may increase costs of monitoring, hiring, training, screening or failing to obtain workers of high quality.

Another almost "stylized fact" in the literature is that the establishment-size effect on wages is higher for white-collar than blue-collar workers. ${ }^{26}$ This is also the case for Côte d'Ivoire. When we run quantile regressions for white-collar workers and blue-collar workers separately and include firm40 as the only firm-size dummy, the result that emerges is consistent with the literature (see figure D1). This pattern can also be explained by the efficiency wage story if it is harder to monitor white-collar workers; if they are more prone to quitting their job voluntarily; or if white-collar workers receive more (firm-specific) training than blue-collar workers. With the data at hand, we cannot verify nor reject these possibilities.

The bottom line is that part of what appears to be union power probably can be explained by establishment-size effects, and that both have a non-negligible effect on wages.

\subsection{Spillover effects from unionized to non-unionized establishments}

The explanation for the absence of a positive union/non-union wage differential could be that wages secured by unionized workers spill-over to raise wages in establishments that are not unionized. Pencavel (1995) set up a model that control for this possibility. He introduces three sectors, only one of which is unionized. In addition to the unionized sector, there is another relatively high wage sector that is influenced by wage-setting practices in the unionized sector. Firms in this sector may pay high wages to discourage unionization or to reduce turnover. Lastly, there is a third sector, which is not influenced by the unionized sector, and where wages are low.

According to this model, unions raise wages not only for their members but also for the high-wage non-unionized workers indirectly influenced by the union negotiations. This leads to

\footnotetext{
${ }^{25}$ Velenchik (1997) controls for the existence of electricity, phone, etc. as proxies for good or bad working conditions. This seems fruitless since establishments with more than 100 employees surely all have these facilities (in compliance with the findings of Velenchik).
} 
an important insight: the premium received by unions is not mirrored in the wage differential between the unionized and non-unionized high-wage sectors. In the absence of unions, wages in both these sectors would decrease and employment in the two sectors would increase, while the third low-wage sector would remain unaffected.

In the analysis above, we have not included such a third sector since the data do not allow it. Instead, we have what can be considered as the two high-wage sectors. Hence, to the extent that such a spillover effect exists, our measure of the impact from unions must be considered a lower bound, since any such spillover effect will lead to a downward bias in the returns to unionization.

The idea of a third sector may also explain part of the establishment-size wage effect since, presumably, small non-unionized firms are less prone to have their wage setting tied to the wage setting in the unionized firms. This does not explain the difference between the premium to blue vs. white-collar workers that we observed above and, hence, cannot be the only reason for the establishment size wage effects.

\section{Conclusion}

\section{Summary of findings}

The objective of this paper has been to analyze possible channels of distortions in the labor markets in Côte d'Ivoire by using enterprise micro-level data. The tool kit used is the technique of quantile regressions, which has proven its usefulness by providing a much more detailed analysis across the distribution than least square techniques could have accomplished. The main findings are the following:

(1) Basic education: The wage premium related to basic education is insignificant across all quantiles when the entire sample is used as well as for all sub-samples.

(2) Higher education: The wage premium from higher education is very significant and positive at all quantiles for all sub-samples, except for firms with less than 40 employees, and the premium is relatively high.

(3) Occupational groups: The effect from occupational groups on wages, on the other hand, are generally very significant, and the heterogeneity both within and between these groups

\footnotetext{
${ }^{26}$ See Schaffner (1998). We define blue collar workers as quality production workers or support staff, while white collar workers include managers, adm/sales, and tech/maintenance.
} 
is found to be substantial, and much larger in unionized enterprises than non-unionized, a finding that questions the actual power of unions.

(4) Union: Union power does not seem to influence wages directly. Union is insignificant in the analysis that includes all observations. When unionized firms are analyzed separately, and a proxy for the degree of unionization is included, the proxy (density) turns out to be statistically insignificant. Union influence and power seem mostly to come through tenure. Tenure is very important in unionized enterprises and not at all so in non-unionized enterprises. Union power also seems to be protecting "vulnerable" minorities in the Ivorian societyprobably mostly "other Africans."

The union-premium may be significantly higher if there is a spill-over effect to the nonunionized firms included in our sample, since this will bias the union premium downwards. Data that include manufacturing firms along with more informal sector firms are welcomed to cast light over this issue.

(5) Establishment-size: Effects from establishment size on wages are pronounced. Workers with comparable observable human capital characteristics earn widely different wages, depending on firm size (in a non-linear fashion). The effect is found much higher for whitecollar workers than for blue-collar workers. Both results are in sync with the literature, and may be explained by efficiency wage considerations.

As previously mentioned, these results do not extend to the entire economy but only hold for the limited and highly selected group of workers employed in the manufacturing sector.

\section{Policy implications and recommendations}

Basic education is not sufficient, and does not lead to higher wages among the "golden league" of workers that the manufacturing sector employees constitute. But since both high education and occupational groups are found very important in generating personal income, formal education is highly recommendable, but should go beyond basic education. Intellectual capital is important, and more of it may lead to a reduction in wage inequality.

Further, setting aside for a moment the possible significant spill-over effects from unionized to non-unionized firms (and hence downward bias in the union premium), labor market distortions do not seem to be of primary concern in the manufacturing sector. The unions show no sign of "monopoly union" power, where - in the extreme case - the unions quote 
the wages. Instead, unions seem more concerned with maintaining and securing jobs. However, unions do lead to inefficiency if the payback to tenure represents rigidly enforced seniority-based promotions that are not based on an increase in the actual level of human capital. This may well be the case since, presumably, if they were based on human capital considerations, tenure would also turn out important in non-unionized enterprises.

A part of the story about tenure, however, is probably related to efficiency wage considerations related to establishment-size wage effects. This means that, even in the absence of unions, segmentation and inefficiencies will still be present as long as firms seek to retain their employees by paying wages above the market clearing level. Education will, in this case, also improve the income distribution through efficiency wage channels, reducing the individual firm's transferable human capital investment which, according to this theory, will reduce the efficiency wage premium.

In any event, the recent decentralization and introduction of enterprise-level bargaining will make it more difficult for union confederations to pursue any aggressive rent-seeking policies, and will reduce the degree to which collective bargaining is politicized. Hence, this policy should be further encouraged. 


\section{References}

Borjas, G. (1996). Labor Economics, New York: McGraw-Hill.

Buchinsky, M. (1998). "Recent Advances in Quantile Regression Models - A Practical Guideline for Empirical Research," The Journal of Human Resources, Vol. XXXIII, No. 1, pp. 88-126.

Buchinsky, M. (1995). "Estimating the Asymptotic Covariance Matrix for Quantile Regression Models: A Monte Carlo Study," Journal of Econometrics, 68:303-38.

Grootaert, C. (1990). "Returns to Formal and Informal Vocational Education in Côte d'Ivoire: The Role of the Structure of the Labor Market," Economics of Education Review, Vol. 9, No. 4, pp. 309-319.

Heckman, J. J. (1979). “Sample Selection Bias as a Specification Error,” Econometrica, Vol. 47, No. 1, pp. 153-161.

Hoddinott, J. (1996). "Wages and Unemployment in an Urban African Labour Market," The Economic Journal, 106, 1610-1626.

Koenker, R. and G. Basset, Jr. (1978). "Regression Quantiles,” Econometrica, Vol. 46, No. 1, pp. 33-50.

Komenan, A. G. and C. Grootaert (1990). "Pay Differences Between Teachers and Other Occupations: Some Empirical Evidence from Côte d'Ivoire, Economics of Education Review, Vol. 9, No. 3, pp. 209-217.

Maloney, W. F. and E. P. Ribeiro (1999). "Efficiency Wage and Union Effects in Labor Demand and Wage Structure in Mexico: An Application of Quantile Analysis," Working Paper, The World Bank.

Mincer, J. (1974). “Schooling, Experience and Earnings,” NBER Working Paper, New York.

Pencavel, J. (1995). “The Role of Labor Unions in Fostering Economic Development," Policy Research Working Paper, No. 1469, The World Bank, Washington, D.C.

Rama, M. (1998). "Wage Misalignment in CFA Countries: Are Labor Market Policies to Blame?," Policy Research Working Paper, No. 1873, The World Bank, Washington D C.

Schaffner, J.A. (1998). "Premiums to employment in larger establishments: evidence from Peru," Journal of Development Economics, Vol. 55 (1998), pp. 81-113.

Van der Gaag, J. and W.P.M. Vijverberg (1989). "Wage Determinants in Côte d'Ivoire: Experience, Credentials, and Human Capital," Economic Development and Cultural Change, No. 37, pp. 371-381. 
Van der Gaag, J. and W.P.M. Vijverberg (1988). "Switching Regression Model for Wage Determinants in the Public and Private Sectors of a Developing Country," Review of Economics and Statistics, 70:244-252.

Van der Gaag, J. and W.P.M. Vijverberg (1991). "The Private Sector in Côte d'Ivoire: Homogeneity or Heterogeneity?," Southern Economic Journal 58(2): 406-21.

Vijverberg, W.P.M. (1994). "Educational Investment and Returns for Women and Men in Côte d'Ivoire," The Journal of Human Resources, XXXVIII (4).

Vijverberg, W.P.M. (1989). "Labor Market Performance as a Determinant of Migration,” LSMS Working Paper, No. 59, The World Bank, Washington D.C.

Velenchik, A.D. (1997). "Government intervention, efficiency wages, and the employer size wage effect in Zimbabwe," Journal of Development Economics, Vol. 53 (1997), pp. 305-338.

Verner, D. (1999a). "Are Wages and Productivity in Zimbabwe Affected by Human Capital Investment and International Trade?," Policy Research Working Paper, No. 2101, The World Bank, Washington D.C.

Verner, D. (1999b). "Wage and Productivity Gaps: Evidence from Ghana," Policy Research Working Paper, No. 2168, The World Bank, Washington, D.C.

Verner, D. (1999c). "What happened to wages in Côte d'Ivoire in the 1980s and 1990s? An application of quantile regressions," Mimeo, The World Bank, Washington, D.C.

World Bank (1995). "Labor and Growth Crisis in Sub-Saharan Africa," Regional Perspectives on World Development Report 1995, The World Bank, Washington, D.C.

World Bank (1998a). Global Development Finance, Washington, D.C.

World Bank (1998b). World Development Indicators, Washington, D.C. 


\section{Appendix A}

\section{Table A1. Basic descriptive statistics}

\begin{tabular}{|c|c|c|c|c|c|c|c|c|c|c|c|c|c|c|}
\hline & \multicolumn{2}{|c|}{ All } & \multicolumn{2}{|c|}{ union members } & \multicolumn{2}{|c|}{ not union members } & \multicolumn{2}{|c|}{ french-lebanese } & \multicolumn{2}{|c|}{ not french- lebanese } & \multicolumn{2}{|c|}{ firm size $\geq 40 \mathrm{empl}$} & \multicolumn{2}{|c|}{ firm size $<40 \mathrm{empl}$} \\
\hline & freq & perc & freq & perc & freq & perc & freq & perc & freq & perc & freq & perc & freq & perc \\
\hline all & 891 & 100.0 & 496 & 100.0 & 395 & 100.0 & 465 & 100.0 & 426 & 100.0 & 528 & 100.0 & 363 & 100.0 \\
\hline Ivorian & 704 & 79.0 & 416 & 83.9 & 288 & 72.9 & 380 & 81.7 & 324 & 76.1 & 445 & 84.3 & 259 & 71.4 \\
\hline other african & 173 & 19.4 & 79 & 15.9 & 94 & 23.8 & 72 & 15.5 & 101 & 23.7 & 77 & 14.6 & 96 & 26.5 \\
\hline other nation & 14 & 1.6 & 1 & 0.2 & 13 & 3.3 & 13 & 2.8 & 1 & 0.2 & 6 & 1.1 & 8 & 2.2 \\
\hline not union & 395 & 44.3 & NA & NA & NA & NA & 151 & 32.5 & 244 & 57.3 & 146 & 27.7 & 249 & 68.6 \\
\hline union & 496 & 55.7 & NA & NA & NA & NA & 314 & 67.5 & 182 & 42.7 & 382 & 72.4 & 114 & 31.4 \\
\hline yrgroup1 (15-25 yrs) & 87 & 9.8 & 18 & 3.6 & 69 & 17.5 & 18 & 3.9 & 69 & 16.2 & 20 & 3.8 & 67 & 18.5 \\
\hline yrgroup2 (26-45 yrs) & 679 & 76.2 & 395 & 79.6 & 284 & 71.9 & 374 & 80.4 & 305 & 71.6 & 424 & 80.3 & 255 & 70.3 \\
\hline yrgroup3 (46-65 yrs) & 125 & 14.0 & 83 & 16.7 & 42 & 10.6 & 73 & 15.7 & 52 & 12.2 & 84 & 15.9 & 41 & 11.3 \\
\hline tenure1 (0-5 yrs) & 412 & 46.2 & 167 & 33.7 & 245 & 62.0 & 177 & 38.1 & 235 & 55.2 & 191 & 36.2 & 221 & 60.9 \\
\hline tenure2 (6-12 yrs) & 245 & 27.5 & 177 & 35.7 & 68 & 17.2 & 141 & 30.3 & 104 & 24.4 & 159 & 30.1 & 86 & 23.7 \\
\hline tenure 3 (more than 12 yrs) & 234 & 26.3 & 152 & 30.7 & 82 & 20.8 & 147 & 31.6 & 87 & 20.4 & 178 & 33.7 & 56 & 15.4 \\
\hline edunone (no education) & 223 & 25.0 & 94 & 19.0 & 129 & 32.7 & 88 & 18.9 & 135 & 31.7 & 94 & 17.8 & 129 & 35.5 \\
\hline edubasic (basic education) & 503 & 56.5 & 316 & 63.7 & 187 & 47.3 & 295 & 63.4 & 208 & 48.8 & 313 & 59.3 & 190 & 52.3 \\
\hline eduhigh (higher education) & 165 & 18.5 & 86 & 17.3 & 79 & 20.0 & 82 & 17.6 & 83 & 19.5 & 121 & 22.9 & 44 & 12.1 \\
\hline manager & 114 & 12.8 & 65 & 13.1 & 49 & 12.4 & 66 & 14.2 & 48 & 11.3 & 83 & 15.7 & 31 & 8.5 \\
\hline administration/sales & 136 & 15.3 & 79 & 15.9 & 57 & 14.4 & 76 & 16.3 & 60 & 14.1 & 90 & 17.1 & 46 & 12.7 \\
\hline technicians/maintenance & 88 & 9.9 & 58 & 11.7 & 30 & 7.6 & 57 & 12.3 & 31 & 7.3 & 61 & 11.6 & 27 & 7.4 \\
\hline qualified production workers & 281 & 31.5 & 167 & 33.7 & 114 & 28.9 & 147 & 31.6 & 134 & 31.5 & 154 & 29.2 & 127 & 35.0 \\
\hline support staff & 272 & 30.5 & 127 & 25.6 & 145 & 36.7 & 119 & 25.6 & 153 & 35.9 & 140 & 26.5 & 132 & 36.4 \\
\hline not french-lebanese owned & 426 & 47.8 & 182 & 36.7 & 244 & 61.8 & NA & NA & NA & NA & 226 & 42.8 & 200 & 55.1 \\
\hline french-lebanese owned & 465 & 52.2 & 314 & 63.3 & 151 & 38.2 & NA & NA & NA & NA & 302 & 57.2 & 163 & 44.9 \\
\hline year 95 & 579 & 65.0 & 307 & 61.9 & 272 & 68.9 & 217 & 46.5 & 362 & 85.0 & 319 & 60.4 & 260 & 71.6 \\
\hline year 96 & 312 & 35.0 & 189 & 38.1 & 123 & 31.1 & 248 & 53.5 & 64 & 15.0 & 209 & 39.6 & 103 & 28.4 \\
\hline firm size $<40$ employees & 363 & 40.7 & 114 & 23.0 & 249 & 63.0 & 163 & 35.0 & 200 & 47.0 & NA & NA & NA & NA \\
\hline firm size $\geq 40$ employees & 528 & 59.3 & 382 & 77.0 & 146 & 37.0 & 302 & 65.0 & 226 & 53.0 & NA & NA & NA & NA \\
\hline never received training & 832 & 93.6 & 456 & 92.3 & 376 & 95.2 & 431 & 93.1 & 401 & 94.1 & 478 & 90.9 & 354 & 97.5 \\
\hline received training & 57 & 6.4 & 38 & 7.7 & 19 & 4.8 & 32 & 6.9 & 25 & 5.9 & 48 & 9.1 & 9 & 2.5 \\
\hline food industry & 216 & 24.2 & 122 & 24.6 & 94 & 23.8 & 76 & 16.3 & 140 & 32.9 & 121 & 22.9 & 95 & 26.2 \\
\hline textile industry & 109 & 12.2 & 30 & 6.1 & 79 & 20.0 & 32 & 6.9 & 77 & 18.1 & 68 & 12.9 & 41 & 11.3 \\
\hline wood industry & 232 & 26.0 & 120 & 24.2 & 112 & 28.4 & 97 & 20.9 & 135 & 31.7 & 133 & 25.2 & 99 & 27.3 \\
\hline metal industry & 263 & 29.5 & 192 & 38.7 & 71 & 18.0 & 218 & 46.9 & 45 & 10.6 & 172 & 32.6 & 91 & 25.1 \\
\hline other industry/not stated & 71 & 8.0 & 32 & 6.5 & 39 & 9.9 & 42 & 9.0 & 29 & 6.8 & 34 & 6.4 & 37 & 10.2 \\
\hline
\end{tabular}


Table A2. Summary Statistics, workers

\begin{tabular}{|c|c|c|c|c|c|c|c|c|c|c|}
\hline \multirow[t]{2}{*}{ variable } & \multicolumn{2}{|c|}{ all } & \multicolumn{2}{|c|}{ union } & \multicolumn{2}{|c|}{ non union } & \multicolumn{2}{|c|}{ french/lebanese } & \multicolumn{2}{|c|}{ non french/lebanese } \\
\hline & mean & std & mean & std & mean & std & mean & std & mean & std \\
\hline monthly wages, all & 128,766 & 186,957 & 124,113 & 131,001 & 134,610 & 239,443 & 159,452 & 224,500 & 95,271 & 126,553 \\
\hline managers & 263,112 & 278,876 & 202,863 & 133,901 & 343,035 & 384,378 & 287,760 & 311,371 & 229,222 & 225,555 \\
\hline $\mathrm{adm} / \mathrm{sales}$ & 189,978 & 239,870 & 179,938 & 206,101 & 203,893 & 281,428 & 226,934 & 269,796 & 143,167 & 187,447 \\
\hline tech/main & 191,142 & 217,369 & 168,669 & 167,471 & 234,590 & 289,238 & 237,032 & 255,823 & 106,762 & 59,159 \\
\hline qual. prod work. & 85,326 & 88,393 & 94,225 & 78,587 & 72,290 & 99,998 & 98,888 & 95,624 & 70,448 & 77,364 \\
\hline support staff & 66,551 & 117,809 & 68,034 & 27,767 & 65,252 & 159,504 & 82,846 & 174,940 & 53,877 & 24,840 \\
\hline firm size (\# empl) & 169.4 & 535.1 & 211.4 & 675.4 & 116.6 & 262.1 & 136.9 & 187.7 & 204.82 & 747.5 \\
\hline value added/empl & $3,927,864$ & $8,088,673$ & $3,106,221$ & $6,661,085$ & $4,959,597$ & $9,493,680$ & $4,110,592$ & $7,526,535$ & $3,728,407$ & $8,665,307$ \\
\hline export share & 24.75 & 34.83 & 27.47 & 36.43 & 21.30 & 32.39 & 26.11 & 35.17 & 23.24 & 34.42 \\
\hline $\begin{array}{l}\text { union density } \\
\text { (share in union) }\end{array}$ & 0.54 & 0.42 & 0.84 & 0.23 & 0.16 & 0.26 & 0.68 & 0.37 & 0.40 & 0.42 \\
\hline
\end{tabular}

Table A3. Summary Statistics, enterprises

\begin{tabular}{|c|c|c|c|c|c|c|c|c|c|c|}
\hline \multirow[t]{2}{*}{ variable } & \multicolumn{2}{|c|}{ All } & \multicolumn{2}{|c|}{ french/lebanese } & \multicolumn{2}{|c|}{ not french/lebanese } & \multicolumn{2}{|c|}{ firm size $\geq 40$} & \multicolumn{2}{|c|}{ firm size $<40$} \\
\hline & mean & std & mean & std & mean & std & mean & std & mean & std \\
\hline export share & 21.8 & 34.7 & 31.4 & 38.3 & 15.3 & 30.7 & 40.24 & 40.00 & 4.48 & 15.09 \\
\hline $\begin{array}{l}\text { value added/empl } \\
\text { union density }\end{array}$ & $3,350,537$ & $8,165,914$ & $4,312,062$ & $8,378,298$ & $2,713,682$ & $8,013,524$ & $3,769,156$ & $7,596,123$ & $2,957,289$ & $8,707,023$ \\
\hline (share in union) & 0.42 & 0.44 & 0.65 & 0.40 & 0.26 & 0.40 & 0.68 & 0.38 & 0.17 & 0.34 \\
\hline
\end{tabular}

Table A4.

\begin{tabular}{lcccccc}
\hline & \multicolumn{2}{c}{ edunone } & \multicolumn{2}{c}{ edubasic } & \multicolumn{2}{c}{ eduhigh } \\
\cline { 2 - 7 } & freq & perc & freq & perc & freq & perc \\
\hline all & $\mathbf{2 2 3}$ & $\mathbf{1 0 0 . 0 0}$ & $\mathbf{5 0 3}$ & $\mathbf{1 0 0 . 0 0}$ & $\mathbf{1 6 5}$ & $\mathbf{1 0 0 . 0 0}$ \\
tenure1 & 117 & 52.47 & 205 & 40.76 & 90 & 54.55 \\
tenure2 & 54 & 24.22 & 149 & 29.62 & 42 & 25.45 \\
tenure3 & 52 & 23.32 & 149 & 29.62 & 33 & 20.00 \\
& & & & & & \\
training & 5 & 2.25 & 36 & 7.17 & 16 & 9.70 \\
no training & 217 & 97.75 & 466 & 92.83 & 149 & 90.30 \\
\hline
\end{tabular}


Table A5. Some percentiles and ratio's of percentiles for monthly wages

\begin{tabular}{|c|c|c|c|c|c|c|c|}
\hline percentiles and ratio's & all & union & non-union & french/lebane & not french/leb & firm size $\geq 40$ & firm size $<40$ \\
\hline \multicolumn{8}{|l|}{ percentiles } \\
\hline 10 & 36,000 & 46,000 & 28,100 & 49,355 & 29,268 & 46,406 & 29,561 \\
\hline 50 & 75,000 & 90,000 & 60,000 & 92,683 & 58,537 & 92,683 & 58,537 \\
\hline 90 & 236,798 & 220,294 & 276,073 & 278,049 & 195,122 & 270,732 & 158,702 \\
\hline \multicolumn{8}{|l|}{ ratio's } \\
\hline $50 / 10$ & 2.08 & 1.96 & 2.14 & 1.88 & 2.00 & 2.00 & 1.98 \\
\hline $90 / 10$ & 6.58 & 4.79 & 9.82 & 5.63 & 6.67 & 5.83 & 5.37 \\
\hline $90 / 50$ & 3.16 & 2.45 & 4.60 & 3.00 & 3.33 & 2.92 & 2.71 \\
\hline
\end{tabular}




\section{Figure A1. Distribution of real monthly wage, various groups}
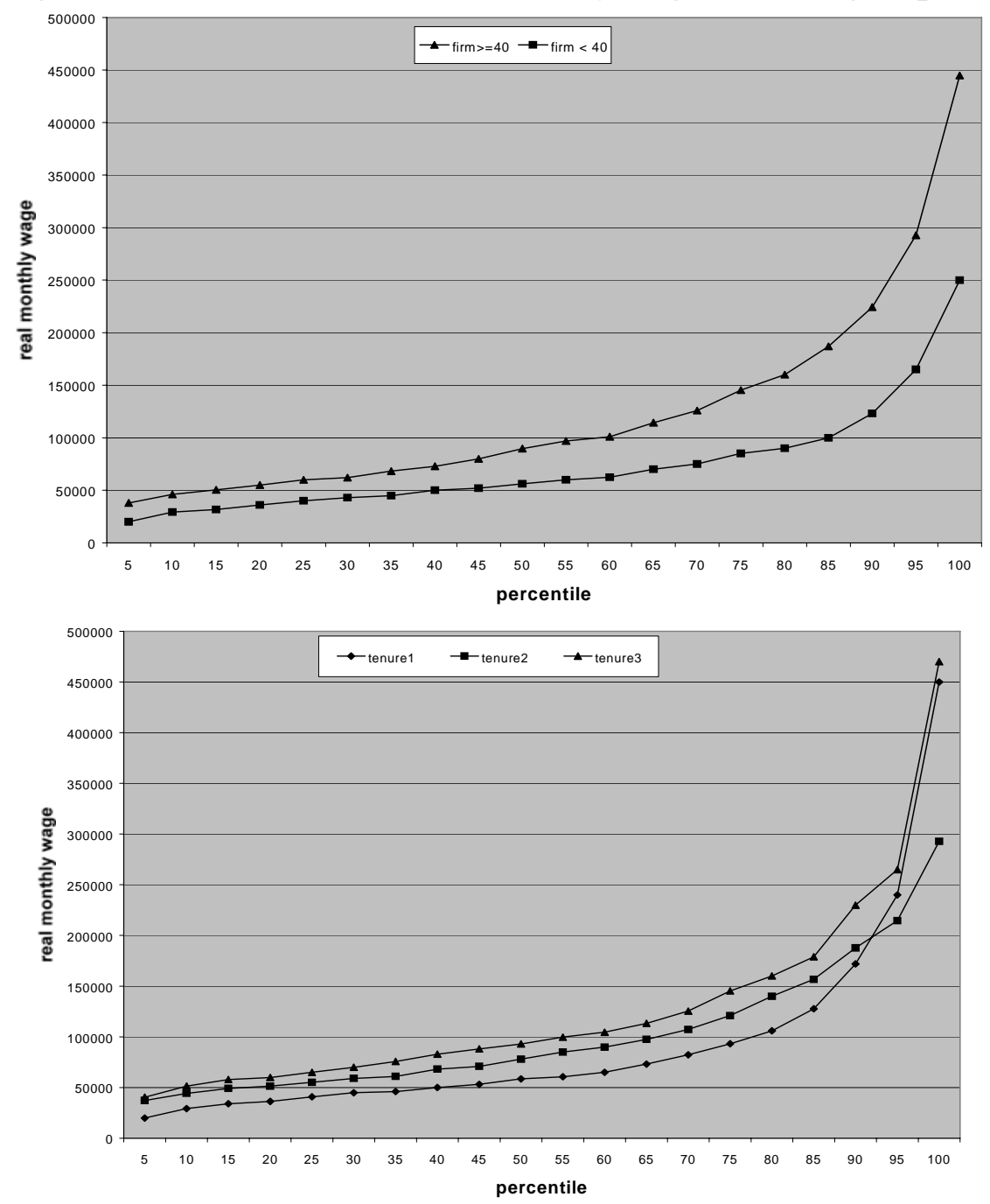
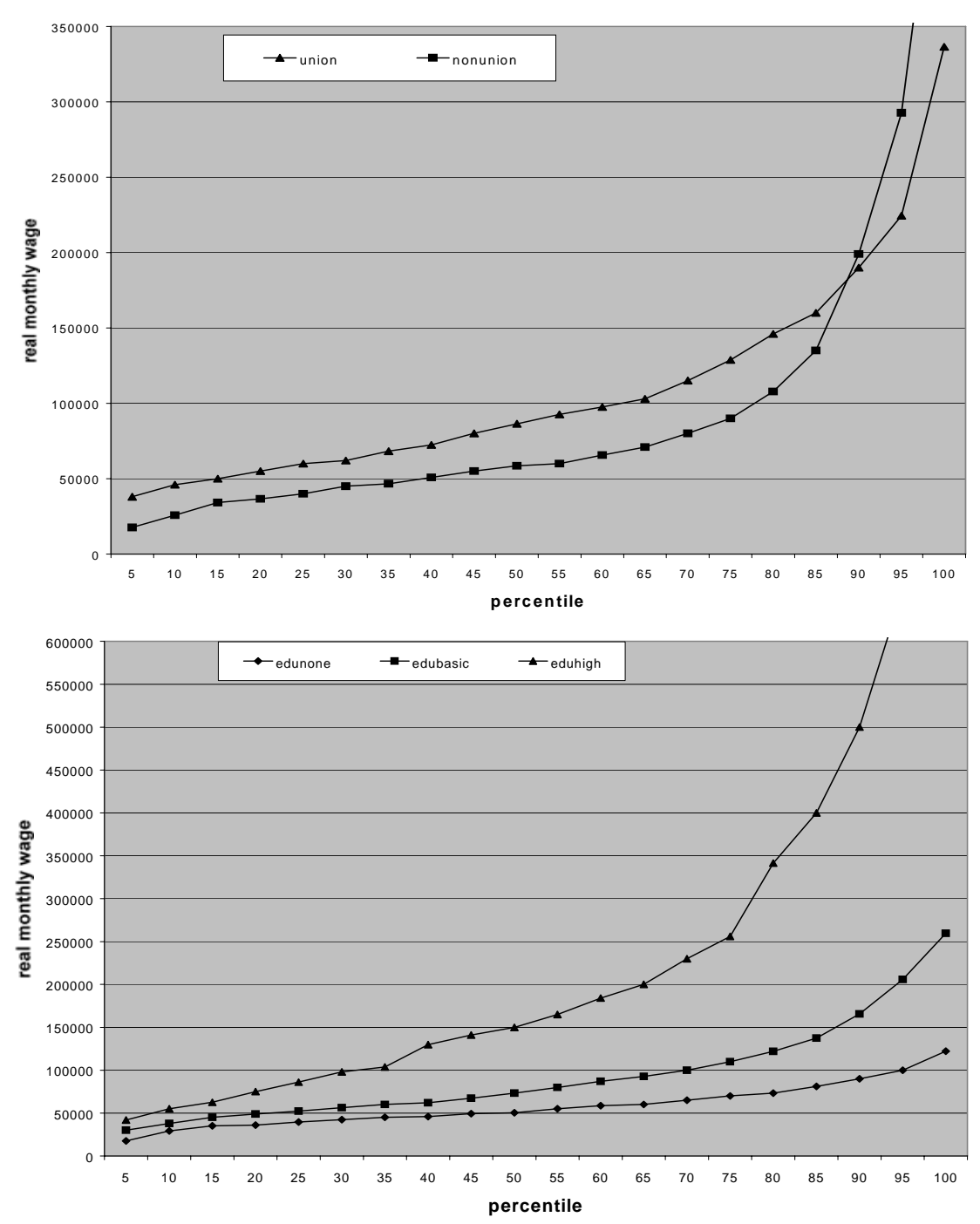


\section{Appendix B, General results (using the entire sample)}

\begin{tabular}{|c|c|c|c|c|c|c|c|c|c|c|c|c|}
\hline \multicolumn{13}{|c|}{ Table B1. Quantile regressions and OLS, all observations } \\
\hline \multirow[t]{3}{*}{$\mathrm{n}=891$} & \multicolumn{10}{|c|}{ quantile regressions } & \multicolumn{2}{|c|}{ OLS } \\
\hline & \multicolumn{2}{|c|}{0.1} & \multicolumn{2}{|c|}{0.25} & \multicolumn{2}{|c|}{0.50} & \multicolumn{2}{|c|}{0.75} & \multicolumn{2}{|c|}{0.90} & \multirow[b]{2}{*}{ coef } & \multirow[b]{2}{*}{ pvalue } \\
\hline & coef & pvalue & coef & pvalue & coef & pvalue & coef & pvalue & coef & pvalue & & \\
\hline constant & 9.3556 & $0.000^{\mathrm{d}}$ & 9.7860 & $0.000^{\mathrm{d}}$ & 10.0287 & $0.000^{\mathrm{d}}$ & 10.2785 & $0.000^{\mathrm{d}}$ & 10.5778 & $0.000^{\mathrm{d}}$ & 9.9651 & $0.000^{\mathrm{d}}$ \\
\hline $\begin{array}{l}\text { individual } \\
\text { characteristics }\end{array}$ & & & & & & & & & & & & \\
\hline yrgroup2 & 0.4546 & $0.002^{\mathrm{d}}$ & 0.2257 & $0.033^{\mathrm{c}}$ & 0.2198 & $0.002^{\mathrm{d}}$ & 0.2442 & $0.000^{\mathrm{d}}$ & 0.2238 & $0.024^{\mathrm{c}}$ & 0.2732 & $0.000^{\mathrm{d}}$ \\
\hline yrgroup3 & 0.5529 & $0.001^{\mathrm{d}}$ & 0.3434 & $0.002^{\mathrm{d}}$ & 0.3868 & $0.000^{\mathrm{d}}$ & 0.3756 & $0.000^{\mathrm{d}}$ & 0.3650 & $0.008^{\mathrm{d}}$ & 0.4473 & $0.000^{\mathrm{d}}$ \\
\hline Ivorian & 0.0980 & 0.166 & 0.1763 & $0.002^{\mathrm{d}}$ & 0.0921 & $0.149^{\mathrm{a}}$ & -0.0143 & 0.821 & -0.1838 & 0.199 & -0.0426 & 0.408 \\
\hline union & 0.0193 & 0.739 & 0.0192 & 0.663 & -0.0645 & 0.303 & -0.1441 & $0.056^{\mathrm{b}}$ & -0.0812 & 0.352 & -0.0868 & $0.074^{\mathrm{b}}$ \\
\hline edubasic & $-1.5 \mathrm{E}-8$ & 1.000 & 0.0494 & 0.337 & 0.0621 & 0.270 & 0.0503 & 0.368 & 0.0927 & 0.261 & 0.1077 & $0.042^{\mathrm{c}}$ \\
\hline eduhigh & 0.2825 & $0.018^{\mathrm{c}}$ & 0.4001 & $0.000^{\mathrm{d}}$ & 0.5569 & $0.000^{\mathrm{d}}$ & 0.6310 & $0.000^{\mathrm{d}}$ & 0.7155 & $0.002^{\mathrm{d}}$ & 0.6208 & $0.000^{\mathrm{d}}$ \\
\hline tenure2 & 0.0324 & 0.650 & 0.0684 & 0.204 & 0.1265 & $0.055^{\mathrm{b}}$ & 0.0572 & 0.347 & -0.1067 & 0.245 & 0.0585 & 0.249 \\
\hline tenure3 & 0.2727 & $0.000^{\mathrm{d}}$ & 0.2461 & $0.000^{\mathrm{d}}$ & 0.2039 & $0.002^{\mathrm{d}}$ & 0.1861 & $0.010^{\mathrm{d}}$ & 0.0541 & 0.600 & 0.1831 & $0.001^{\mathrm{d}}$ \\
\hline $\begin{array}{l}\text { french/leban } \\
\text { occupation }\end{array}$ & 0.1070 & $0.071^{b}$ & 0.1348 & $0.001^{\mathrm{d}}$ & 0.1425 & $0.022^{\mathrm{c}}$ & 0.2277 & $0.000^{\mathrm{d}}$ & 0.2075 & $0.017^{\mathrm{c}}$ & 0.1448 & $0.003^{\mathrm{d}}$ \\
\hline manager & 0.6907 & $0.000^{\mathrm{d}}$ & 0.5443 & $0.000^{\mathrm{d}}$ & 0.7100 & $0.000^{\mathrm{d}}$ & 0.9154 & $0.000^{\mathrm{d}}$ & 1.1033 & $0.000^{\mathrm{d}}$ & 0.7401 & $0.000^{\mathrm{d}}$ \\
\hline $\mathrm{adm} / \mathrm{sales}$ & 0.2300 & $0.031^{\mathrm{c}}$ & 0.2842 & $0.002^{\mathrm{d}}$ & 0.4467 & $0.000^{\mathrm{d}}$ & 0.6524 & $0.000^{\mathrm{d}}$ & 0.6715 & $0.000^{\mathrm{d}}$ & 0.4780 & $0.000^{\mathrm{d}}$ \\
\hline tech/mainten & 0.3607 & $0.001^{\mathrm{d}}$ & 0.3417 & $0.000^{\mathrm{d}}$ & 0.5996 & $0.000^{\mathrm{d}}$ & 0.7028 & $0.000^{\mathrm{d}}$ & 0.7461 & $0.000^{\mathrm{d}}$ & 0.5750 & $0.000^{\mathrm{d}}$ \\
\hline $\begin{array}{l}\text { qualified prod. } \\
\text { industry }\end{array}$ & 0.1542 & $0.018^{c}$ & 0.0689 & $0.127^{\mathrm{a}}$ & 0.1515 & $0.002^{\mathrm{d}}$ & 0.1272 & $0.000^{\mathrm{d}}$ & 0.2009 & $0.022^{\mathrm{c}}$ & 0.1430 & $0.005^{\mathrm{d}}$ \\
\hline food & 0.1125 & 0.383 & 0.0615 & 0.454 & 0.2300 & $0.004^{\mathrm{d}}$ & 0.2718 & $0.000^{\mathrm{d}}$ & 0.2954 & $0.002^{\mathrm{d}}$ & 0.1856 & $0.009^{d}$ \\
\hline wood & 0.1384 & 0.267 & 0.0550 & 0.455 & 0.0968 & 0.210 & 0.1290 & $0.060^{\mathrm{b}}$ & 0.1877 & $0.040^{\mathrm{c}}$ & 0.1121 & $0.114^{\mathrm{a}}$ \\
\hline metal & 0.3006 & $0.008^{\mathrm{d}}$ & 0.1411 & $0.057^{\mathrm{b}}$ & 0.1941 & $0.007^{\mathrm{d}}$ & 0.2099 & $0.005^{\mathrm{d}}$ & 0.2459 & $0.033^{\mathrm{c}}$ & 0.2629 & $0.000^{\mathrm{d}}$ \\
\hline $\begin{array}{l}\text { other/no stated } \\
\text { firm size }\end{array}$ & 0.1667 & 0.213 & $0.0169^{c}$ & 0.855 & 0.0205 & 0.864 & 0.1877 & $0.047^{\mathrm{c}}$ & 0.1524 & 0.293 & 0.1317 & 0.151 \\
\hline small firm & 0.3477 & $0.000^{\mathrm{d}}$ & 0.2975 & $0.000^{\mathrm{d}}$ & 0.2439 & $0.002^{\mathrm{d}}$ & 0.3523 & $0.000^{\mathrm{d}}$ & 0.5534 & $0.000^{\mathrm{d}}$ & 0.4012 & $0.000^{\mathrm{d}}$ \\
\hline medium firm & 0.1334 & 0.251 & 0.2270 & $0.002^{\mathrm{d}}$ & 0.2481 & $0.008^{\mathrm{d}}$ & 0.4127 & $0.000^{d}$ & 0.5323 & $0.000^{\mathrm{d}}$ & 0.3327 & $0.000^{d}$ \\
\hline large firm & 0.4067 & $0.000^{d}$ & 0.3572 & $0.000^{\mathrm{d}}$ & 0.2930 & $0.000^{\mathrm{d}}$ & 0.3996 & $0.000^{\mathrm{d}}$ & 0.5272 & $0.000^{\mathrm{d}}$ & 0.4956 & $0.000^{\mathrm{d}}$ \\
\hline value added & $1.1 \mathrm{E}-8$ & $0.000^{\mathrm{d}}$ & $1.1 L^{-0}$ & $0.001^{\mathrm{d}}$ & $8.0 \mathrm{E}-9$ & & $1.1 \mathrm{E}-8$ & $0.002^{\mathrm{d}}$ & $1.0 \mathrm{E}-8$ & $0.101^{\mathrm{a}}$ & $1.2 \mathrm{E}-8$ & $0.000^{\mathrm{d}}$ \\
\hline year dummy & 0.1111 & $0.126^{\mathrm{a}}$ & 0.1808 & $0.001^{\mathrm{d}}$ & 0.1943 & $0.000^{\mathrm{d}}$ & 0.1901 & $0.001^{\mathrm{d}}$ & 0.2382 & $0.012^{\mathrm{c}}$ & 0.1981 & $0.000^{\mathrm{d}}$ \\
\hline
\end{tabular}

Note: a-significance at the $15 \%$ level; $\mathrm{b}-10 \%$; $\mathrm{c}-5 \%$; $\mathrm{d}-1 \%$. 
Table B2. Tests of equality of coefficients across quantiles, all observations

Tests are one-sided t-tests, $\mathrm{H}_{0}$ : coefficient $\left(\mathrm{Q}_{\mathrm{A}}\right)=\operatorname{coefficient}\left(\mathrm{Q}_{\mathrm{B}}\right)$. The t-statistic is given as the numerical value. Data are pooled over the two years 1995 and 1996 and are for men only.

a-significant at the $15 \%$ level
b-significant at the $10 \%$ level
c-significant at the $5 \%$ level
d-significant at the $1 \%$ level

\begin{tabular}{cccccccccc}
\hline & \multicolumn{4}{c}{ yrgroup2 } & \multicolumn{2}{c}{ yrgroup3 } & \multicolumn{2}{c}{ Ivorian } & \multicolumn{2}{c}{ union } \\
\hline $\mathrm{Q}_{\mathrm{A}}$ & $\mathrm{Q}_{\mathrm{B}}$ & t-stat & $\mathrm{p}$-value & t-stat & $\mathrm{p}$-value & t-stat & $\mathrm{p}$-value & t-stat & $\mathrm{p}$-value \\
\hline 0.1 & 0.25 & 3.23 & $0.0363^{\mathrm{c}}$ & 2.04 & $0.0768^{\mathrm{b}}$ & 1.29 & $0.1283^{\mathrm{a}}$ & 0.00 & 0.4995 \\
0.1 & 0.50 & 2.70 & $0.0504^{\mathrm{b}}$ & 0.92 & 0.1688 & 0.01 & 0.4712 & 1.16 & $0.1408^{\mathrm{a}}$ \\
0.1 & 0.75 & 1.88 & $0.0855^{\mathrm{b}}$ & 0.95 & 0.1645 & 1.46 & $0.1135^{\mathrm{a}}$ & 3.50 & $0.0309^{\mathrm{c}}$ \\
0.1 & 0.90 & 2.01 & $0.0783^{\mathrm{b}}$ & 0.93 & 0.1677 & 3.27 & $0.0355^{\mathrm{c}}$ & 0.93 & 0.1682 \\
0.25 & 0.50 & 0.00 & 0.4753 & 0.14 & 0.3519 & 1.86 & $0.0866^{\mathrm{b}}$ & 2.19 & $0.0696^{\mathrm{b}}$ \\
0.25 & 0.75 & 0.03 & 0.4343 & 0.05 & 0.4125 & 6.44 & $0.0057^{\mathrm{d}}$ & 4.68 & $0.0154^{\mathrm{c}}$ \\
0.25 & 0.90 & 0.00 & 0.4943 & 0.02 & 0.4508 & 6.19 & 0.0065 & 1.17 & $0.1401^{\mathrm{a}}$ \\
0.50 & 0.75 & 0.15 & 0.3471 & 0.01 & 0.4540 & 2.62 & $0.0529^{\mathrm{b}}$ & 1.50 & $0.1107^{\mathrm{a}}$ \\
0.50 & 0.90 & 0.00 & 0.4841 & 0.02 & 0.4413 & 3.88 & $0.0246^{\mathrm{c}}$ & 0.03 & 0.4271 \\
0.75 & 0.90 & 0.05 & 0.4149 & 0.01 & 0.4657 & 1.90 & $0.0842^{\mathrm{b}}$ & 0.65 & 0.2105 \\
\hline
\end{tabular}

\begin{tabular}{cccccccccc}
\hline & \multicolumn{4}{c}{ edubasic } & \multicolumn{2}{c}{ eduhigh } & \multicolumn{2}{c}{ tenure2 } & \multicolumn{2}{c}{ tenure3 } \\
\hline $\mathrm{Q}_{\mathrm{A}}$ & $\mathrm{Q}_{\mathrm{B}}$ & $\mathrm{t}-$-stat & $\mathrm{p}$-value & $\mathrm{t}$-stat & $\mathrm{p}$-value & t-stat & $\mathrm{p}$-value & t-stat & $\mathrm{p}$-value \\
\hline 0.1 & 0.25 & 0.62 & 0.2149 & 1.29 & $0.1281^{\mathrm{a}}$ & 0.35 & 0.2784 & 0.21 & 0.3253 \\
0.1 & 0.50 & 0.78 & 0.1888 & 3.66 & $0.0281^{\mathrm{c}}$ & 1.28 & $0.1287^{\mathrm{a}}$ & 0.73 & 0.1971 \\
0.1 & 0.75 & 0.40 & 0.2625 & 6.51 & $0.0055^{\mathrm{d}}$ & 0.09 & 0.3804 & 0.99 & 0.1598 \\
0.1 & 0.90 & 0.81 & 0.1841 & 2.95 & $0.0432^{\mathrm{c}}$ & 1.65 & $0.0999^{\mathrm{b}}$ & 3.94 & $0.0238^{\mathrm{c}}$ \\
0.25 & 0.50 & 0.06 & 0.4038 & 2.07 & $0.0752^{\mathrm{b}}$ & 0.93 & 0.1681 & 0.58 & 0.2234 \\
0.25 & 0.75 & 0.00 & 0.4943 & 3.91 & $0.0242^{\mathrm{c}}$ & 0.03 & 0.4338 & 0.79 & 0.1875 \\
0.25 & 0.90 & 0.22 & 0.3195 & 1.83 & $0.0880^{\mathrm{b}}$ & 3.26 & $0.0358^{\mathrm{c}}$ & 3.32 & $0.0344^{\mathrm{c}}$ \\
0.50 & 0.75 & 0.04 & 0.4165 & 0.41 & 0.2604 & 1.29 & $0.1281^{\mathrm{a}}$ & 0.07 & 0.3932 \\
0.50 & 0.90 & 0.13 & 0.3580 & 0.47 & 0.2464 & 5.84 & $0.0080^{\mathrm{d}}$ & 2.09 & $0.0744^{\mathrm{b}}$ \\
0.75 & 0.90 & 0.43 & 0.2550 & 0.19 & 0.3327 & 4.14 & $0.0211^{\mathrm{c}}$ & 2.22 & $0.0681^{\mathrm{b}}$ \\
\hline
\end{tabular}

\begin{tabular}{|c|c|c|c|c|c|c|c|c|c|}
\hline \multirow[b]{2}{*}{$\mathrm{Q}_{\mathrm{A}}$} & \multirow[b]{2}{*}{$\mathrm{Q}_{\mathrm{B}}$} & \multicolumn{2}{|c|}{ manager } & \multicolumn{2}{|c|}{ admsales } & \multicolumn{2}{|c|}{ techmain } & \multicolumn{2}{|c|}{ qprod } \\
\hline & & t-stat & p-value & t-stat & p-value & t-stat & p-value & t-stat & $\mathrm{p}$-value \\
\hline 0.1 & 0.25 & 1.11 & $0.1464^{\mathrm{a}}$ & 0.32 & 0.2847 & 0.03 & 0.4272 & 2.12 & $0.0731^{b}$ \\
\hline 0.1 & 0.50 & 0.01 & 0.4563 & 3.32 & $0.0344^{\mathrm{c}}$ & 4.49 & $0.0172^{c}$ & 0.00 & 0.4842 \\
\hline 0.1 & 0.75 & 1.60 & $0.1030^{\mathrm{a}}$ & 13.65 & $0.0001^{\mathrm{d}}$ & 4.46 & $0.0176^{\mathrm{c}}$ & 0.11 & 0.3675 \\
\hline 0.1 & 0.90 & 3.07 & $0.0401^{\mathrm{c}}$ & 5.98 & $0.0074^{\mathrm{d}}$ & 4.47 & $0.0174^{\mathrm{c}}$ & 0.19 & 0.3301 \\
\hline 0.25 & 0.50 & 2.36 & $0.0623^{\mathrm{b}}$ & 2.62 & $0.0528^{\mathrm{b}}$ & 8.34 & $0.0020^{\mathrm{d}}$ & 2.69 & $0.0508^{b}$ \\
\hline 0.25 & 0.75 & 11.21 & $0.0004^{\mathrm{d}}$ & 12.69 & $0.0002^{\mathrm{d}}$ & 6.52 & $0.0054^{\mathrm{d}}$ & 0.73 & 0.1963 \\
\hline 0.25 & 0.90 & 8.21 & $0.0022^{\mathrm{d}}$ & 4.96 & $0.0131^{\mathrm{c}}$ & 6.59 & $0.0052^{\mathrm{d}}$ & 1.89 & $0.0846^{\mathrm{b}}$ \\
\hline 0.50 & 0.75 & 3.96 & $0.0234^{\mathrm{c}}$ & 6.04 & $0.0071^{\mathrm{d}}$ & 0.70 & 0.2018 & 0.21 & 0.3228 \\
\hline 0.50 & 0.90 & 4.29 & $0.0193^{\mathrm{c}}$ & 2.19 & $0.0698^{\mathrm{b}}$ & 1.00 & 0.1586 & 0.34 & 0.2790 \\
\hline \multirow[t]{2}{*}{0.75} & 0.90 & 1.23 & $0.1343^{\mathrm{a}}$ & 0.02 & 0.4398 & 0.09 & 0.3832 & 1.13 & $0.1440^{\mathrm{a}}$ \\
\hline & & \multicolumn{2}{|c|}{ yeard96 } & \multicolumn{2}{|c|}{ franlib } & \multicolumn{2}{|c|}{ valadper } & \multicolumn{2}{|c|}{ smallf } \\
\hline $\mathrm{Q}_{\mathrm{A}}$ & $\mathrm{QB}_{\mathrm{B}}$ & t-stat & $\mathrm{p}$-value & t-stat & p-value & t-stat & p-value & t-stat & p-value \\
\hline 0.1 & 0.25 & 1.21 & $0.1356^{\mathrm{a}}$ & 0.22 & 0.3214 & 0.06 & 0.4020 & 0.32 & 0.2848 \\
\hline 0.1 & 0.50 & 1.17 & $0.1399^{a}$ & 0.20 & 0.3276 & 0.77 & 0.1902 & 0.96 & 0.1639 \\
\hline 0.1 & 0.75 & 0.79 & 0.1875 & 2.37 & $0.0622^{\mathrm{b}}$ & 0.04 & 0.4215 & 0.00 & 0.4844 \\
\hline 0.1 & 0.90 & 1.14 & $0.1428^{\mathrm{a}}$ & 0.99 & 0.1604 & 0.02 & 0.4437 & 1.83 & $0.0883^{b}$ \\
\hline 0.25 & 0.50 & 0.07 & 0.3978 & 0.02 & 0.4431 & 0.79 & 0.1865 & 0.52 & 0.2352 \\
\hline 0.25 & 0.75 & 0.02 & 0.4443 & 2.32 & $0.0642^{\mathrm{b}}$ & 0.00 & 0.4900 & 0.34 & 0.2792 \\
\hline 0.25 & 0.90 & 0.29 & 0.2944 & 0.64 & 0.2123 & 0.00 & 0.4833 & 3.33 & $0.0341^{\mathrm{c}}$ \\
\hline 0.50 & 0.75 & 0.01 & 0.4707 & 1.64 & $0.1002^{\mathrm{a}}$ & 0.59 & 0.2216 & 1.82 & $0.0890^{\mathrm{b}}$ \\
\hline 0.50 & 0.90 & 0.23 & 0.3154 & 0.45 & 0.2508 & 0.13 & 0.3587 & 5.60 & $0.0091^{\mathrm{d}}$ \\
\hline 0.75 & 0.90 & 0.33 & 0.2831 & 0.07 & 0.3954 & 0.00 & 0.4868 & 2.77 & $0.0482^{\mathrm{c}}$ \\
\hline
\end{tabular}


Table B2 (continued). Tests of equality of coefficients across quantiles, all observations

Tests are one-sided t-tests, $\mathrm{H}_{0}$ : $\operatorname{coefficient}\left(\mathrm{Q}_{\mathrm{A}}\right)=\operatorname{coefficient}\left(\mathrm{Q}_{B}\right)$. The $\mathrm{t}$-statistic is given as the numerical value. Data are pooled over the two years 1995 and 1996 and are for men only.

a-significant at the $15 \%$ level b-significant at the $10 \%$ level c-significant at the $5 \%$ level $\mathrm{d}$-significant at the $1 \%$ level

\begin{tabular}{cccccc}
\hline \multicolumn{9}{c}{ mediumf } & \multicolumn{2}{c}{ largef } \\
\hline $\mathrm{Q}_{\mathrm{A}}$ & $\mathrm{Q}_{\mathrm{B}}$ & $\mathrm{t}$-stat & $\mathrm{p}$-value & t-stat & p-value \\
\hline 0.1 & 0.25 & 0.81 & 0.1840 & 0.39 & 0.2651 \\
0.1 & 0.50 & 0.74 & 0.1944 & 1.26 & $0.1308^{\mathrm{a}}$ \\
0.1 & 0.75 & 4.44 & $0.0178^{\mathrm{c}}$ & 0.00 & 0.4734 \\
0.1 & 0.90 & 6.48 & $0.0056^{\mathrm{d}}$ & 0.93 & 0.1680 \\
0.25 & 0.50 & 0.07 & 0.3982 & 0.76 & 0.1913 \\
0.25 & 0.75 & 4.11 & $0.0215^{\mathrm{c}}$ & 0.19 & 0.3333 \\
0.25 & 0.90 & 5.71 & $0.0086^{\mathrm{d}}$ & 1.94 & $0.0819^{\mathrm{b}}$ \\
0.50 & 0.75 & 4.17 & $0.0207^{\mathrm{c}}$ & 1.94 & $0.0821^{\mathrm{b}}$ \\
0.50 & 0.90 & 4.45 & $0.0176^{\mathrm{c}}$ & 3.99 & $0.0231^{\mathrm{c}}$ \\
0.75 & 0.90 & 1.12 & $0.1452^{\mathrm{a}}$ & 1.53 & $0.1085^{\mathrm{a}}$ \\
\hline \multicolumn{7}{c}{} & & & \\
\hline \multicolumn{7}{c}{ metal $^{\mathrm{r}}$} & & other industry \\
\hline $\mathrm{Q}_{\mathrm{A}}$ & $\mathrm{Q}_{\mathrm{B}}$ & $\mathrm{t}$-stat & $\mathrm{p}$-value & $\mathrm{t}$-stat & $\mathrm{p}$-value \\
\hline 0.1 & 0.25 & 2.34 & $0.0632^{\mathrm{b}}$ & 1.40 & $0.1182^{\mathrm{a}}$ \\
0.1 & 0.50 & 0.87 & 0.1759 & 0.86 & 0.1770 \\
0.1 & 0.75 & 0.53 & 0.2325 & 0.02 & 0.4454 \\
0.1 & 0.90 & 0.14 & 0.3540 & 0.01 & 0.4696 \\
0.25 & 0.50 & 0.61 & 0.2179 & 0.00 & 0.4870 \\
0.25 & 0.75 & 0.62 & 0.2154 & 2.21 & $0.0689^{\mathrm{b}}$ \\
0.25 & 0.90 & 0.67 & 0.2059 & 0.72 & 0.1977 \\
0.50 & 0.75 & 0.05 & 0.4125 & 2.32 & $0.0640^{\mathrm{b}}$ \\
0.50 & 0.90 & 0.19 & 0.3320 & 0.66 & 0.2091 \\
0.75 & 0.90 & 0.11 & 0.3702 & 0.08 & 0.3918 \\
\hline
\end{tabular}


Figure B1
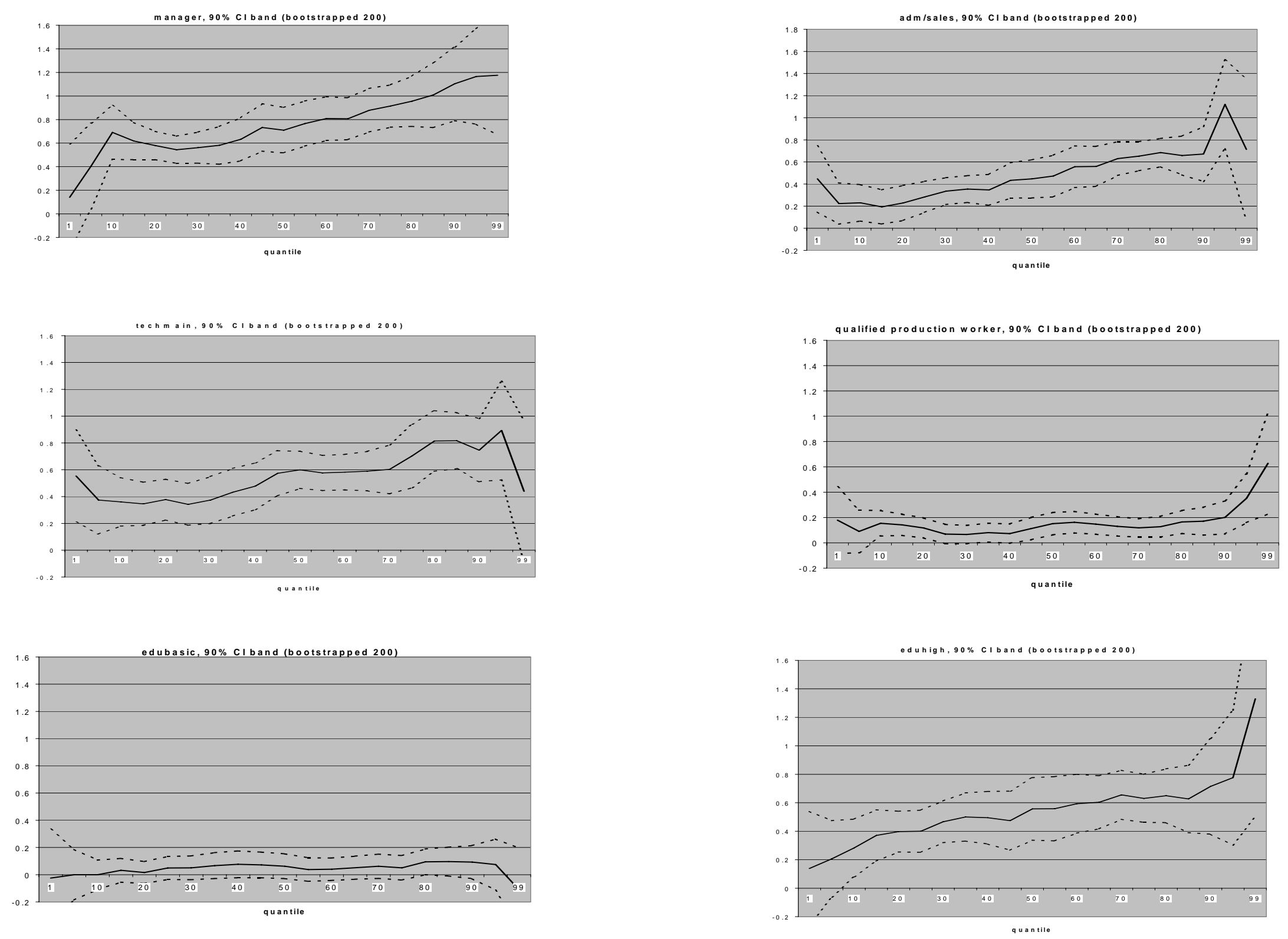


\section{Appendix C, Results when splitting union and non-union members}

Table C1. Regression results, Workers in unionized firms.

\begin{tabular}{|c|c|c|c|c|c|c|c|c|c|c|c|c|}
\hline \multirow{3}{*}{$\begin{array}{l}n=634 \\
\# \text { firms }=68\end{array}$} & \multicolumn{10}{|c|}{ quantile regressions } & \multicolumn{2}{|c|}{ OLS } \\
\hline & \multicolumn{2}{|c|}{0.1} & \multicolumn{2}{|c|}{0.25} & \multicolumn{2}{|c|}{0.50} & \multicolumn{2}{|c|}{0.75} & \multicolumn{2}{|c|}{0.90} & \multirow[b]{2}{*}{ coef } & \multirow[b]{2}{*}{ pvalue } \\
\hline & coef & pvalue & coef & pvalue & coef & pvalue & coef & pvalue & coef & pvalue & & \\
\hline constant & 9.8539 & $0.000^{\mathrm{d}}$ & 9.9580 & $0.000^{\mathrm{d}}$ & 10.2771 & $0.000^{\mathrm{d}}$ & 10.5651 & $0.000^{\mathrm{d}}$ & 10.7920 & $0.000^{d}$ & 10.2709 & $0.000^{\mathrm{d}}$ \\
\hline \multicolumn{13}{|l|}{$\begin{array}{l}\text { individual } \\
\text { characteristics }\end{array}$} \\
\hline yrgroup2 & 0.0862 & 0.453 & 0.1034 & 0.254 & 0.1685 & $0.053^{b}$ & 0.1950 & 0.191 & 0.3969 & $0.049^{c}$ & 0.2606 & $0.021^{\mathrm{c}}$ \\
\hline yrgroup 3 & 0.2221 & $0.104^{\mathrm{a}}$ & 0.1807 & $0.118^{\mathrm{a}}$ & 0.2735 & $0.032^{\mathrm{c}}$ & 0.3881 & $0.037^{\mathrm{c}}$ & 0.5514 & $0.018^{c}$ & 0.4298 & $0.001^{\mathrm{d}}$ \\
\hline Ivorian & 0.0485 & 0.540 & 0.0493 & 0.490 & -0.0279 & 0.758 & -0.2590 & $0.024^{\mathrm{c}}$ & -0.4328 & $0.007^{\mathrm{d}}$ & -0.2119 & $0.002^{\mathrm{d}}$ \\
\hline union density & -0.0735 & 0.548 & -0.0321 & 0.745 & -0.0299 & 0.790 & -0.0432 & 0.771 & -0.4554 & $0.083^{b}$ & -0.1857 & $0.080^{\mathrm{b}}$ \\
\hline edubasic & -0.0263 & 0.694 & $1.3 \mathrm{E}-8$ & 1.000 & 0.0136 & 0.797 & 0.0919 & 0.172 & 0.1282 & 0.197 & 0.1265 & $0.057^{b}$ \\
\hline eduhigh & 0.4805 & $0.000^{\mathrm{d}}$ & 0.5243 & $0.000^{\mathrm{d}}$ & 0.5309 & $0.000^{\mathrm{d}}$ & 0.6734 & $0.000^{\mathrm{d}}$ & 0.7233 & $0.001^{\mathrm{d}}$ & 0.7130 & $0.000^{\mathrm{d}}$ \\
\hline tenure2 & 0.1479 & $0.104^{\mathrm{a}}$ & 0.0764 & 0.162 & 0.1972 & $0.005^{\mathrm{d}}$ & 0.0740 & 0.395 & -0.1449 & 0.294 & 0.0862 & 0.165 \\
\hline tenure 3 & 0.3460 & $0.000^{\mathrm{d}}$ & 0.2654 & $0.000^{\mathrm{d}}$ & 0.2568 & $0.001^{\mathrm{d}}$ & 0.2836 & $0.004^{\mathrm{d}}$ & 0.0811 & 0.557 & 0.2245 & $0.000^{\mathrm{d}}$ \\
\hline french/leban & 0.0800 & 0252 & 0.0716 & $0.127^{\mathrm{a}}$ & 0.1244 & $0.071^{\mathrm{b}}$ & 0.0902 & 0.291 & 0.1359 & 0.194 & 0.1120 & $0.065^{\mathrm{b}}$ \\
\hline $\begin{array}{l}\text { occupation } \\
\text { manager }\end{array}$ & 0.5693 & $0.000^{\mathrm{d}}$ & 06025 & $0.000^{\mathrm{d}}$ & 0.8250 & $0.000^{\mathrm{d}}$ & 1.0304 & $0.000^{\mathrm{d}}$ & 1.2901 & $0.000^{\mathrm{d}}$ & 0.8420 & $0.000^{d}$ \\
\hline $\mathrm{adm} / \mathrm{sales}$ & 0.2930 & $0.016^{\mathrm{c}}$ & 0.3521 & $0.000^{\mathrm{d}}$ & 0.6199 & $0.000^{\mathrm{d}}$ & 0.8772 & $0.000^{\mathrm{d}}$ & 1.0357 & $0.000^{\mathrm{d}}$ & 0.6368 & $0.000^{\mathrm{d}}$ \\
\hline tech/mainten & 0.2779 & $0.017^{\mathrm{c}}$ & 0.2562 & $0.004^{\mathrm{d}}$ & 0.6087 & $0.000^{\mathrm{d}}$ & 0.6879 & $0.000^{\mathrm{d}}$ & 0.8715 & $0.000^{\mathrm{d}}$ & 0.5603 & $0.000^{d}$ \\
\hline $\begin{array}{l}\text { qualified prod. } \\
\text { industry }\end{array}$ & 0.1296 & $0.097^{\mathrm{b}}$ & 0.1032 & $0.024^{\mathrm{c}}$ & 0.1676 & $0.009^{d}$ & 0.2696 & $0.001^{\mathrm{d}}$ & 0.4232 & $0.000^{\mathrm{d}}$ & 0.2231 & $0.001^{\mathrm{d}}$ \\
\hline food & 0.1358 & 0.599 & 0.2410 & $0.045^{c}$ & 0.1581 & 0.169 & 0.3192 & $0.002^{\mathrm{d}}$ & 0.5583 & $0.000^{\mathrm{d}}$ & 0.2292 & $0.019^{c}$ \\
\hline wood & 0.1816 & 0.472 & 0.1012 & 0.373 & -0.0815 & 0.444 & 0.1195 & 0.250 & 0.4199 & $0.007^{\mathrm{d}}$ & 0.1238 & 0.219 \\
\hline metal & 0.3776 & $0.131^{\mathrm{a}}$ & 0.2610 & $0.029^{c}$ & 0.0875 & 0.411 & 0.1721 & $0.082^{b}$ & 0.4128 & $0.007^{\mathrm{d}}$ & 0.2522 & $0.010^{d}$ \\
\hline $\begin{array}{l}\text { other/no stated } \\
\text { firm size }\end{array}$ & 0.2193 & 0.435 & 0.1586 & 0.296 & 0.1468 & 0.391 & 0.3227 & $0.016^{\mathrm{c}}$ & 0.5641 & $0.008^{d}$ & 0.2310 & $0.082^{b}$ \\
\hline small firm & 0.2202 & $0.122^{\mathrm{a}}$ & 0.3024 & $0.009^{d}$ & 0.2689 & $0.030^{\mathrm{c}}$ & 0.2265 & $0.099^{b}$ & 0.4744 & $0.107^{\mathrm{a}}$ & 0.2877 & $0.009^{d}$ \\
\hline medium firm & -0.0130 & 0.929 & 0.0751 & 0.520 & 0.1386 & 0.316 & 0.1308 & 0.411 & 0.2837 & 0.381 & 0.0895 & 0.414 \\
\hline large firm & 0.2816 & $0.044^{\mathrm{c}}$ & 0.3665 & $0.001^{\mathrm{d}}$ & 0.2301 & $0.067^{\mathrm{b}}$ & 0.1543 & 0.286 & 0.3661 & 0.240 & 0.2847 & $0.009^{d}$ \\
\hline value added & $1.0 \mathrm{E}-8$ & $0.020^{\mathrm{c}}$ & $1.3 \mathrm{E}-8$ & $0.000^{\mathrm{d}}$ & $8.3 \mathrm{E}-9$ & $0.031^{\mathrm{c}}$ & $1.0 \mathrm{E}-8$ & $0.055^{\mathrm{b}}$ & $1.3 \mathrm{E}-8$ & $0.129^{\mathrm{a}}$ & $1.2 \mathrm{E}-8$ & $0.000^{d}$ \\
\hline year dummy & 0.1551 & $0.066^{\mathrm{b}}$ & 0.2948 & $0.000^{\mathrm{d}}$ & 0.2213 & $0.000^{\mathrm{d}}$ & 0.1962 & $0.005^{\mathrm{d}}$ & 0.0919 & 0.425 & 0.2203 & $0.000^{\mathrm{d}}$ \\
\hline \multicolumn{13}{|c|}{ Workers in non-unionized firms. } \\
\hline \multirow{3}{*}{$\#$ firms $=59$} & \multicolumn{10}{|c|}{ quantile regressions } & & \\
\hline & & & & & & & & & & & & \\
\hline & coef & pvalue & coef & pvalue & coef & pvalue & coef & pvalue & coef & pvalue & coef & pvalue \\
\hline constant & 9.2417 & $0.000^{d}$ & 9.5993 & $0.000^{d}$ & 9.9875 & 0.000 & 10.2812 & $0.000^{d}$ & 10.5652 & $0.000^{d}$ & 9.9802 & $0.000^{\mathrm{d}}$ \\
\hline $\begin{array}{l}\text { individual } \\
\text { characteristics }\end{array}$ & & & & & & & & & & & & \\
\hline yrgroup2 & 0.5072 & $0.052^{b}$ & 0.4157 & $0.017^{\mathrm{c}}$ & 0.1772 & $0.122^{\mathrm{a}}$ & 0.2609 & $0.001^{\mathrm{d}}$ & 0.2535 & $0.002^{\mathrm{d}}$ & 0.2458 & $0.012^{\mathrm{c}}$ \\
\hline yrgroup3 & 0.6670 & $0.009^{d}$ & 0.4244 & $0.079^{b}$ & 0.3629 & $0.015^{\mathrm{c}}$ & 0.3827 & $0.024^{c}$ & 0.3430 & 0.191 & 0.4824 & $0.001^{\mathrm{d}}$ \\
\hline Ivorian & 0.1598 & 0.296 & 0.4157 & $0.002^{\mathrm{d}}$ & 0.2696 & $0.012^{\mathrm{c}}$ & 0.0610 & 0.428 & -0.0506 & 0.722 & 0.1532 & $0.044^{\mathrm{c}}$ \\
\hline edubasic & 0.1034 & 0.476 & $-4.0 \mathrm{E}-8$ & 1.000 & -0.0418 & 0.630 & 0.0356 & 0.623 & -0.0989 & 0.352 & 0.0208 & 0.805 \\
\hline eduhigh & 0.1324 & 0.618 & 0.0078 & 0.962 & 0.1567 & 0.435 & 0.5257 & $0.074^{\mathrm{b}}$ & 0.4892 & $0.134^{\mathrm{a}}$ & 0.3565 & $0.006^{\mathrm{d}}$ \\
\hline tenure 2 & 0.1636 & 0.378 & 0.0165 & 0.901 & 0.1518 & $0.090^{\mathrm{b}}$ & 0.0780 & 0.374 & 0.0927 & 0.336 & 0.1041 & 0.237 \\
\hline tenure 3 & 0.3528 & $0.106^{\mathrm{a}}$ & 0.2664 & $0.077^{b}$ & 0.3414 & $0.018^{c}$ & 0.1738 & $0.135^{\mathrm{a}}$ & 0.2469 & $0.099^{b}$ & 0.2607 & $0.028^{\mathrm{c}}$ \\
\hline french/leban & 0.1949 & 0.286 & 0.1380 & 0.312 & 0.3314 & $0.009^{d}$ & 0.2376 & $0.015^{\mathrm{c}}$ & 0.2579 & $0.066^{\mathrm{b}}$ & 0.3186 & $0.000^{d}$ \\
\hline occupation & & & & & & & & & & & & \\
\hline manager & 0.0203 & 0.957 & 0.5545 & $0.057^{b}$ & 0.4414 & $0.063^{b}$ & 0.5263 & $0.100^{b}$ & 0.8175 & $0.025^{c}$ & 0.4460 & $0.003^{d}$ \\
\hline adm/sales & 0.0310 & 0.889 & 0.0223 & 0.902 & 0.0723 & 0.663 & 0.2276 & 0.294 & 0.5095 & $0.009^{d}$ & 0.1554 & 0.206 \\
\hline tech/mainten & 0.6118 & $0.015^{\mathrm{c}}$ & 0.5076 & $0.003^{\mathrm{d}}$ & 0.4521 & $0.007^{\mathrm{d}}$ & 0.7168 & $0.004^{\mathrm{d}}$ & 0.7832 & $0.019^{c}$ & 0.6479 & $0.000^{\mathrm{d}}$ \\
\hline $\begin{array}{l}\text { qualified prod. } \\
\text { industry }\end{array}$ & 0.2064 & 0.259 & 0.0515 & 0.651 & -0.0040 & 0.965 & 0.0313 & 0.685 & 0.0814 & 0.421 & 0.0237 & 0.773 \\
\hline food & 0.0316 & 0.884 & 0.1503 & 0.325 & 0.2329 & $0.045^{c}$ & 0.2062 & $0.039^{c}$ & 0.0615 & 0.596 & 0.1340 & 0.229 \\
\hline wood & -0.0332 & 0.870 & 0.0564 & 0.685 & 0.1385 & 0.268 & 0.0903 & 0.326 & 0.0995 & 0.384 & -0.0178 & 0.855 \\
\hline metal & 0.2611 & 0.348 & 0.2395 & 0.290 & 0.2797 & $0.138^{\mathrm{a}}$ & 0.2275 & $0.102^{\mathrm{a}}$ & 0.1533 & 0.729 & 0.2389 & $0.124^{\mathrm{a}}$ \\
\hline $\begin{array}{l}\text { other/no stated } \\
\text { firm size }\end{array}$ & 0.1665 & 0.423 & 0.1092 & 0.499 & 0.1762 & 0.244 & 0.1199 & 0.469 & 0.1676 & 0.460 & 0.1232 & 0.301 \\
\hline small firm & 0.2346 & 0.278 & 0.1011 & 0.510 & -0.0951 & 0.407 & -0.1321 & 0.277 & 0.1134 & 0.527 & 0.0212 & 0.854 \\
\hline medium firm & 0.3674 & $0.054^{\mathrm{b}}$ & 0.4200 & $0.003^{d}$ & 0.4778 & $0.000^{\mathrm{d}}$ & 0.4661 & $0.001^{\mathrm{d}}$ & 0.3864 & $0.013^{c}$ & 0.5590 & $0.000^{\mathrm{d}}$ \\
\hline large firm & 0.7515 & $0.006^{d}$ & 0.3879 & $0.082^{b}$ & 0.6619 & $0.010^{\mathrm{d}}$ & 0.9066 & 0.014 & 0.8511 & 0.219 & 0.8478 & $0.000^{\mathrm{d}}$ \\
\hline value added & $1.3 \mathrm{E}-8$ & 0.182 & $6.9 \mathrm{E}-9$ & 0.286 & 4.6E-9 & 0.391 & 4.7E-9 & 0.343 & $3.3 \mathrm{E}-9$ & 0.928 & $6.2 \mathrm{E}-9$ & 0.160 \\
\hline year dummy & -0.0336 & 0.818 & 0.1047 & 0.423 & 0.2046 & $0.041^{\mathrm{c}}$ & 0.2214 & $0.017^{\mathrm{c}}$ & 0.3363 & $0.018^{c}$ & 0.1823 & $0.052^{b}$ \\
\hline
\end{tabular}

Note: $a-$ significance at the $15 \%$ level; $b-10 \%$; $c-5 \%$; $-1 \%$. 


\section{Table C2. Tests of equality of coefficients across quantiles, unionized enterprises only}

Tests are one-sided t-tests, $\mathrm{H}_{0}$ : $\operatorname{coefficient}\left(\mathrm{Q}_{\mathrm{A}}\right)=\operatorname{coefficient}\left(\mathrm{Q}_{\mathrm{B}}\right)$. The $\mathrm{t}$-statistic is given as the numerical value.

a-significant at the $15 \%$ level

b-significant at the $10 \%$ level

c-significant at the $5 \%$ level

d-significant at the $1 \%$ level

\begin{tabular}{|c|c|c|c|c|c|c|c|c|c|}
\hline \multirow[b]{2}{*}{$\mathrm{Q}_{\mathrm{A}}$} & \multirow[b]{2}{*}{$\mathrm{Q}_{\mathrm{B}}$} & \multicolumn{2}{|c|}{ yrgroup2 } & \multicolumn{2}{|c|}{ yrgroup3 } & \multicolumn{2}{|c|}{ Ivorian } & \multicolumn{2}{|c|}{ union density } \\
\hline & & t-stat & p-value & t-stat & p-value & t-stat & p-value & t-stat & p-value \\
\hline 0.1 & 0.25 & 0.02 & 0.4384 & 0.11 & 0.3674 & 0.00 & 0.4959 & 0.16 & 0.3450 \\
\hline 0.1 & 0.50 & 0.45 & 0.2508 & 0.12 & 0.3663 & 0.57 & 0.2252 & 0.10 & 0.3768 \\
\hline 0.1 & 0.75 & 0.45 & 0.2521 & 0.77 & 0.1905 & 6.00 & 0.0073 & 0.03 & 0.4348 \\
\hline 0.1 & 0.90 & 1.72 & 0.0949 & 1.72 & 0.0951 & 7.38 & 0.0034 & 1.81 & 0.0897 \\
\hline 0.25 & 0.50 & 0.46 & 0.2491 & 0.57 & 0.2246 & 0.96 & 0.1639 & 0.00 & 0.4913 \\
\hline 0.25 & 0.75 & 0.43 & 0.2568 & 1.57 & 0.1056 & 7.41 & 0.0034 & 0.01 & 0.4717 \\
\hline 0.25 & 0.90 & 1.93 & 0.0827 & 2.45 & 0.0589 & 8.29 & 0.0021 & 2.66 & 0.0518 \\
\hline 0.50 & 0.75 & 0.05 & 0.4129 & 0.65 & 0.2095 & 4.64 & 0.0158 & 0.01 & 0.4610 \\
\hline 0.50 & 0.90 & 1.24 & 0.1327 & 1.46 & 0.1140 & 5.78 & 0.0083 & 2.85 & 0.0461 \\
\hline \multirow[t]{2}{*}{0.75} & 0.90 & 1.16 & 0.1415 & 0.58 & 0.2236 & 1.46 & 0.1141 & 3.39 & 0.0330 \\
\hline & & \multicolumn{2}{|c|}{ edubasic } & \multicolumn{2}{|c|}{ eduhigh } & \multicolumn{2}{|c|}{ tenure 2} & \multicolumn{2}{|c|}{ tenure3 } \\
\hline $\mathrm{Q}_{\mathrm{A}}$ & $\mathrm{Q}_{\mathrm{B}}$ & t-stat & p-value & t-stat & p-value & t-stat & p-value & t-stat & p-value \\
\hline 0.1 & 0.25 & 0.21 & 0.3223 & 0.17 & 0.3390 & 0.92 & 0.1689 & 0.95 & 0.1652 \\
\hline 0.1 & 0.50 & 0.38 & 0.2700 & 0.12 & 0.3666 & 0.25 & 0.3082 & 0.77 & 0.1902 \\
\hline 0.1 & 0.75 & 1.52 & 0.1089 & 1.50 & 0.1109 & 0.45 & 0.2515 & 0.28 & 0.3000 \\
\hline 0.1 & 0.90 & 2.19 & 0.0696 & 1.16 & 0.1412 & 2.88 & 0.0452 & 2.42 & 0.0600 \\
\hline 0.25 & 0.50 & 0.07 & 0.3981 & 0.00 & 0.4750 & 3.62 & 0.0288 & 0.01 & 0.4557 \\
\hline 0.25 & 0.75 & 1.13 & 0.1442 & 1.33 & 0.1247 & 0.00 & 0.4894 & 0.03 & 0.4284 \\
\hline 0.25 & 0.90 & 1.72 & 0.0948 & 0.91 & 0.1696 & 1.86 & 0.0864 & 1.34 & 0.1234 \\
\hline 0.50 & 0.75 & 1.05 & 0.1534 & 1.39 & 0.1193 & 1.95 & 0.0814 & 0.09 & 0.3823 \\
\hline 0.50 & 0.90 & 1.45 & 0.1142 & 0.74 & 0.1957 & 4.30 & 0.0193 & 1.31 & 0.1368 \\
\hline \multirow[t]{2}{*}{0.75} & 0.90 & 0.18 & 0.3359 & 0.07 & 0.3982 & 2.47 & 0.0582 & 2.42 & 0.0601 \\
\hline & & \multicolumn{2}{|c|}{ manager } & \multicolumn{2}{|c|}{ admsales } & \multicolumn{2}{|c|}{ techmain } & \multicolumn{2}{|c|}{ qprod } \\
\hline $\mathrm{Q}_{\mathrm{A}}$ & $\mathrm{Q}_{\mathrm{B}}$ & t-stat & p-value & t-stat & p-value & t-stat & p-value & t-stat & p-value \\
\hline 0.1 & 0.25 & 0.08 & 0.3881 & 0.28 & 0.2977 & 0.04 & 0.4225 & 0.20 & 0.3287 \\
\hline 0.1 & 0.50 & 2.66 & 0.0516 & 4.67 & 0.0156 & 5.18 & 0.0012 & 0.24 & 0.3105 \\
\hline 0.1 & 0.75 & 6.99 & 0.0042 & 14.71 & 0.0001 & 7.15 & 0.0039 & 2.14 & 0.0721 \\
\hline 0.1 & 0.90 & 11.29 & 0.0004 & 13.75 & 0.0001 & 11.65 & 0.0004 & 5.00 & 0.0129 \\
\hline 0.25 & 0.50 & 3.83 & 0.0254 & 6.05 & 0.0071 & 10.4 & 0.0007 & 1.45 & 0.1145 \\
\hline 0.25 & 0.75 & 8.90 & 0.0015 & 19.53 & 0.0000 & 10.73 & 0.0006 & 4.29 & 0.0194 \\
\hline 0.25 & 0.90 & 13.64 & 0.0001 & 15.95 & 0.0001 & 14.10 & 0.0001 & 7.09 & 0.0040 \\
\hline 0.50 & 0.75 & 2.56 & 0.0550 & 6.02 & 0.0072 & 0.41 & 0.2604 & 2.26 & 0.6650 \\
\hline 0.50 & 0.90 & 6.25 & 0.0064 & 5.95 & 0.0075 & 2.50 & 0.0572 & 4.89 & 0.0137 \\
\hline 0.75 & 0.90 & 2.79 & 0.0478 & 1.37 & 0.1214 & 1.75 & 0.0931 & 2.38 & 0.0618 \\
\hline
\end{tabular}


Table C2 (continued). Tests of equality of coefficients across quantiles, unionized enterprises only

Tests are one-sided t-tests, $\mathrm{H}_{0}$ : $\operatorname{coefficient}\left(\mathrm{Q}_{\mathrm{A}}\right)=\operatorname{coefficient}\left(\mathrm{Q}_{B}\right)$. The $\mathrm{t}$-statistic is given as the numerical value.

a-significant at the $15 \%$ level

b-significant at the $10 \%$ level

c-significant at the $5 \%$ level

d-significant at the $1 \%$ level

\begin{tabular}{|c|c|c|c|c|c|c|c|c|c|}
\hline \multirow[b]{2}{*}{$\mathrm{Q}_{\mathrm{A}}$} & \multirow[b]{2}{*}{$\mathrm{Q}_{\mathrm{B}}$} & \multicolumn{2}{|c|}{ yeard96 } & \multicolumn{2}{|c|}{ franlib } & \multicolumn{2}{|c|}{ valadper } & \multicolumn{2}{|c|}{ smallf } \\
\hline & & t-stat & $\mathrm{p}$-value & t-stat & p-value & t-stat & p-value & t-stat & p-value \\
\hline 0.1 & 0.25 & 4.24 & 0.0200 & 0.02 & 0.4382 & 0.48 & 0.2442 & 0.37 & 0.2710 \\
\hline 0.1 & 0.50 & 0.65 & 0.2099 & 0.33 & 0.2842 & 0.17 & 0.3417 & 0.10 & 0.3739 \\
\hline 0.1 & 0.75 & 0.21 & 0.3226 & 0.01 & 0.4571 & 0.00 & 0.4905 & 0.00 & 0.4869 \\
\hline 0.1 & 0.90 & 0.21 & 0.3244 & 0.21 & 0.3217 & 0.09 & 0.3830 & 0.81 & 0.1837 \\
\hline 0.25 & 0.50 & 1.54 & 0.1078 & 0.80 & 0.1856 & 1.48 & 0.1125 & 0.08 & 0.3888 \\
\hline 0.25 & 0.75 & 1.53 & 0.1080 & 0.05 & 0.4111 & 0.18 & 0.3365 & 0.21 & 0.3237 \\
\hline 0.25 & 0.90 & 2.45 & 0.0589 & 0.33 & 0.2829 & 0.01 & 0.4701 & 0.40 & 0.2637 \\
\hline 0.50 & 0.75 & 0.16 & 0.3461 & 0.26 & 0.3068 & 0.18 & 0.3347 & 0.09 & 0.3824 \\
\hline 0.50 & 0.90 & 1.17 & 0.1400 & 0.01 & 0.4583 & 0.23 & 0.3164 & 0.61 & 0.2172 \\
\hline \multirow[t]{2}{*}{0.75} & 0.90 & 0.91 & 0.1705 & 0.19 & 0.3303 & 0.12 & 0.3668 & 1.07 & 0.1512 \\
\hline & & \multicolumn{2}{|c|}{ mediumf } & \multicolumn{2}{|c|}{ largef } & \multicolumn{2}{|c|}{ food } & \multicolumn{2}{|c|}{ wood } \\
\hline $\mathrm{Q}_{\mathrm{A}}$ & $\mathrm{Q}_{\mathrm{B}}$ & t-stat & p-value & t-stat & p-value & t-stat & p-value & t-stat & p-value \\
\hline 0.1 & 0.25 & 0.35 & 0.2759 & 0.42 & 0.2583 & 0.25 & 0.3077 & 0.16 & 0.3469 \\
\hline 0.1 & 0.50 & 0.85 & 0.1787 & 0.12 & 0.3648 & 0.01 & 0.4643 & 1.27 & 0.1301 \\
\hline 0.1 & 0.75 & 0.49 & 0.2429 & 0.47 & 0.2474 & 0.48 & 0.2439 & 0.06 & 0.4009 \\
\hline 0.1 & 0.90 & 0.94 & 0.1669 & 0.08 & 0.3856 & 2.01 & 0.0785 & 0.65 & 0.2104 \\
\hline 0.25 & 0.50 & 0.24 & 0.3134 & 1.20 & 0.1371 & 0.50 & 0.2402 & 3.16 & 0.0380 \\
\hline 0.25 & 0.75 & 0.11 & 0.3726 & 1.74 & 0.0940 & 0.27 & 0.3011 & 0.02 & 0.4457 \\
\hline 0.25 & 0.90 & 0.53 & 0.2333 & 0.00 & 0.4996 & 2.46 & 0.0586 & 2.78 & 0.0478 \\
\hline 0.50 & 0.75 & 0.00 & 0.4796 & 0.31 & 0.2878 & 2.32 & 0.0643 & 3.34 & 0.0340 \\
\hline 0.50 & 0.90 & 0.26 & 0.3056 & 0.26 & 0.3037 & 5.36 & 0.0105 & 8.05 & 0.0024 \\
\hline 0.75 & 0.90 & 0.38 & 0.2701 & 0.77 & 0.1902 & 3.13 & 0.0387 & 4.49 & 0.0173 \\
\hline
\end{tabular}

\begin{tabular}{cccccc}
\hline \multicolumn{9}{c}{ metal } & \multicolumn{2}{c}{ other industry } \\
\hline $\mathrm{Q}_{\mathrm{A}}$ & $\mathrm{Q}_{\mathrm{B}}$ & t-stat & $\mathrm{p}$-value & t-stat & p-value \\
\hline 0.1 & 0.25 & 0.35 & 0.2781 & 0.07 & 0.3993 \\
0.1 & 0.50 & 1.55 & 0.1072 & 0.06 & 0.4010 \\
0.1 & 0.75 & 0.71 & 0.1998 & 0.12 & 0.3621 \\
0.1 & 0.90 & 0.02 & 0.4498 & 1.02 & 0.1568 \\
0.25 & 0.50 & 2.37 & 0.0619 & 0.00 & 0.4722 \\
0.25 & 0.75 & 0.43 & 0.2572 & 0.78 & 0.1891 \\
0.25 & 0.90 & 0.75 & 0.1933 & 2.78 & 0.0479 \\
0.50 & 0.75 & 0.66 & 0.2077 & 1.17 & 0.1397 \\
0.50 & 0.90 & 4.10 & 0.0217 & 3.18 & 0.0375 \\
0.75 & 0.90 & 3.56 & 0.0298 & 1.95 & 0.0816 \\
\hline
\end{tabular}


Table C3. Tests of equality of coefficients across quantiles, non-unionized enterprises only

Tests are one-sided t-tests, $\mathrm{H}_{0}$ : $\operatorname{coefficient}\left(\mathrm{Q}_{\mathrm{A}}\right)=\operatorname{coefficient}\left(\mathrm{Q}_{B}\right)$. The t-statistic is given as the numerical value.

a-significant at the $15 \%$ level

b-significant at the $10 \%$ level

c-significant at the $5 \%$ level

d-significant at the $1 \%$ level

\begin{tabular}{cccccccc}
\hline & \multicolumn{2}{c}{ yrgroup2 } & \multicolumn{2}{c}{ yrgroup3 } & \multicolumn{2}{c}{ Ivorian } \\
\hline $\mathrm{Q}_{\mathrm{A}}$ & $\mathrm{Q}_{\mathrm{B}}$ & t-stat & $\mathrm{p}$-value & t-stat & $\mathrm{p}$-value & t-stat & $\mathrm{p}$-value \\
\hline 0.1 & 0.25 & 0.21 & 0.3243 & 1.05 & 0.1528 & 3.40 & 0.0333 \\
0.1 & 0.50 & 2.05 & 0.0767 & 1.44 & 0.1158 & 0.42 & 0.2590 \\
0.1 & 0.75 & 1.13 & 0.1439 & 1.14 & 0.1432 & 0.32 & 0.2859 \\
0.1 & 0.90 & 1.12 & 0.1457 & 0.73 & 0.1970 & 1.13 & 0.1445 \\
0.25 & 0.50 & 2.55 & 0.0559 & 0.09 & 0.3832 & 1.34 & 0.1244 \\
0.25 & 0.75 & 0.89 & 0.1727 & 0.03 & 0.4340 & 5.89 & 0.0080 \\
0.25 & 0.90 & 0.90 & 0.1725 & 0.05 & 0.4107 & 7.21 & 0.0039 \\
0.50 & 0.75 & 0.60 & 0.2195 & 0.01 & 0.4546 & 4.73 & 0.0154 \\
0.50 & 0.90 & 0.40 & 0.2632 & 0.00 & 0.4747 & 4.86 & 0.0142 \\
0.75 & 0.90 & 0.01 & 0.4628 & 0.02 & 0.4397 & 1.10 & 0.1476 \\
\hline
\end{tabular}

\begin{tabular}{|c|c|c|c|c|c|c|c|c|c|}
\hline \multirow[b]{2}{*}{$\mathrm{Q}_{\mathrm{A}}$} & \multirow[b]{2}{*}{$\mathrm{Q}_{\mathrm{B}}$} & \multicolumn{2}{|c|}{ edubasic } & \multicolumn{2}{|c|}{ eduhigh } & \multicolumn{2}{|c|}{ tenure2 } & \multicolumn{2}{|c|}{ tenure3 } \\
\hline & & t-stat & p-value & t-stat & p-value & t-stat & p-value & t-stat & $\mathrm{p}$-value \\
\hline 0.1 & 0.25 & 0.57 & 0.2262 & 0.26 & 0.3048 & 0.80 & 0.1854 & 0.24 & 0.3112 \\
\hline 0.1 & 0.50 & 0.82 & 0.1836 & 0.01 & 0.4700 & 0.00 & 0.4753 & 0.00 & 0.4775 \\
\hline 0.1 & 0.75 & 0.18 & 0.3349 & 1.08 & 0.1496 & 0.19 & 0.3338 & 0.78 & 0.1888 \\
\hline 0.1 & 0.90 & 1.28 & 0.1293 & 0.72 & 0.1989 & 0.12 & 0.3647 & 0.24 & 0.3140 \\
\hline 0.25 & 0.50 & 0.14 & 0.3563 & 0.47 & 0.2461 & 1.42 & 0.1174 & 0.28 & 0.2986 \\
\hline 0.25 & 0.75 & 0.08 & 0.3879 & 3.14 & 0.0389 & 0.21 & 0.3222 & 0.35 & 0.2764 \\
\hline 0.25 & 0.90 & 0.42 & 0.2576 & 1.87 & 0.0863 & 0.26 & 0.3038 & 0.01 & 0.4571 \\
\hline 0.50 & 0.75 & 0.90 & 0.1722 & 2.20 & 0.0698 & 0.85 & 0.1784 & 1.92 & 0.0836 \\
\hline 0.50 & 0.90 & 0.25 & 0.3071 & 1.08 & 0.1502 & 0.31 & 0.2894 & 0.39 & 0.2671 \\
\hline \multirow[t]{2}{*}{0.75} & 0.90 & 2.55 & 0.0560 & 0.02 & 0.4500 & 0.03 & 0.4301 & 0.33 & 0.2818 \\
\hline & & \multicolumn{2}{|c|}{ manager } & \multicolumn{2}{|c|}{ admsales } & \multicolumn{2}{|c|}{ techmain } & \multicolumn{2}{|c|}{ qprod } \\
\hline $\mathrm{Q}_{\mathrm{A}}$ & $\mathrm{Q}_{\mathrm{B}}$ & t-stat & p-value & t-stat & p-value & t-stat & p-value & t-stat & p-value \\
\hline 0.1 & 0.25 & 3.12 & 0.0393 & 0.00 & 0.4825 & 0.27 & 0.3024 & 1.17 & 0.1407 \\
\hline 0.1 & 0.50 & 1.3 & 0.1274 & 0.03 & 0.4309 & 0.35 & 0.2782 & 1.55 & 0.1071 \\
\hline 0.1 & 0.75 & 1.24 & 0.1337 & 0.46 & 0.2481 & 0.11 & 0.3678 & 0.95 & 0.1657 \\
\hline 0.1 & 0.90 & 2.58 & 0.0548 & 2.64 & 0.0529 & 0.16 & 0.3471 & 0.42 & 0.2599 \\
\hline 0.25 & 0.50 & 0.20 & 0.3275 & 0.09 & 0.3850 & 0.10 & 0.3781 & 0.28 & 0.2988 \\
\hline 0.25 & 0.75 & 0.01 & 0.4686 & 0.78 & 0.1891 & 0.76 & 0.1928 & 0.03 & 0.4327 \\
\hline 0.25 & 0.90 & 0.46 & 0.2499 & 3.85 & 0.0254 & 0.50 & 0.2406 & 0.05 & 0.4152 \\
\hline 0.50 & 0.75 & 0.10 & 0.3764 & 0.73 & 0.1977 & 1.93 & 0.0830 & 0.17 & 0.3404 \\
\hline 0.50 & 0.90 & 1.31 & 0.1269 & 4.59 & 0.0166 & 0.86 & 0.1778 & 0.58 & 0.2238 \\
\hline 0.75 & 0.90 & 0.95 & 0.1660 & 2.43 & 0.0602 & 0.04 & 0.4241 & 0.34 & 0.2798 \\
\hline
\end{tabular}


Table C3 (continued). Tests of equality of coefficients across quantiles, non-unionized enterprises only

Tests are one-sided t-tests, $\mathrm{H}_{0}$ : $\operatorname{coefficient}\left(\mathrm{Q}_{\mathrm{A}}\right)=\operatorname{coefficient}\left(\mathrm{Q}_{B}\right)$. The $\mathrm{t}$-statistic is given as the numerical value.

a-significant at the $15 \%$ level

b-significant at the $10 \%$ level

c-significant at the $5 \%$ level

d-significant at the $1 \%$ level

\begin{tabular}{|c|c|c|c|c|c|c|c|c|c|}
\hline \multirow[b]{2}{*}{$\mathrm{Q}_{\mathrm{A}}$} & \multirow[b]{2}{*}{$\mathrm{Q}_{\mathrm{B}}$} & \multicolumn{2}{|c|}{ yeard96 } & \multicolumn{2}{|c|}{ franlib } & \multicolumn{2}{|c|}{ valadper } & \multicolumn{2}{|c|}{ smallf } \\
\hline & & t-stat & $\mathrm{p}$-value & t-stat & p-value & t-stat & p-value & t-stat & p-value \\
\hline 0.1 & 0.25 & 0.82 & 0.1835 & 0.13 & 0.3604 & 0.50 & 0.2402 & 0.54 & 0.2314 \\
\hline 0.1 & 0.50 & 1.69 & 0.0976 & 0.52 & 0.2350 & 0.75 & 0.1938 & 2.37 & 0.0624 \\
\hline 0.1 & 0.75 & 1.61 & 0.1030 & 0.04 & 0.4181 & 0.62 & 0.2156 & 2.49 & 0.0578 \\
\hline 0.1 & 0.90 & 3.21 & 0.0372 & 0.08 & 0.3905 & 0.68 & 0.2054 & 0.21 & 0.3232 \\
\hline 0.25 & 0.50 & 0.62 & 0.2167 & 2.41 & 0.0611 & 0.19 & 0.3313 & 2.06 & 0.0765 \\
\hline 0.25 & 0.75 & 0.61 & 0.2182 & 0.46 & 0.2499 & 0.11 & 0.3694 & 1.76 & 0.0928 \\
\hline 0.25 & 0.90 & 2.02 & 0.0784 & 0.50 & 0.2411 & 0.20 & 0.3273 & 0.00 & 0.4780 \\
\hline 0.50 & 0.75 & 0.02 & 0.4380 & 0.65 & 0.2100 & 0.00 & 0.4942 & 0.08 & 0.3864 \\
\hline 0.50 & 0.90 & 0.88 & 0.1752 & 0.25 & 0.3087 & 0.04 & 0.4233 & 1.25 & 0.1326 \\
\hline \multirow[t]{2}{*}{0.75} & 0.90 & 1.00 & 0.1594 & 0.03 & 0.4308 & 0.06 & 0.4031 & 2.52 & 0.0568 \\
\hline & & \multicolumn{2}{|c|}{ mediumf } & \multicolumn{2}{|c|}{ largef } & \multicolumn{2}{|c|}{ food } & \multicolumn{2}{|c|}{ wood } \\
\hline $\mathrm{Q}_{\mathrm{A}}$ & $\mathrm{Q}_{\mathrm{B}}$ & t-stat & p-value & t-stat & p-value & t-stat & p-value & t-stat & p-value \\
\hline 0.1 & 0.25 & 0.09 & 0.3821 & 2.51 & 0.0572 & 0.38 & 0.2701 & 0.25 & 0.3077 \\
\hline 0.1 & 0.50 & 0.30 & 0.2917 & 0.06 & 0.3995 & 0.85 & 0.1784 & 0.69 & 0.2039 \\
\hline 0.1 & 0.75 & 0.17 & 0.3415 & 0.19 & 0.3313 & 0.56 & 0.2267 & 0.33 & 0.2840 \\
\hline 0.1 & 0.90 & 0.01 & 0.4696 & 0.02 & 0.4452 & 0.02 & 0.4506 & 0.35 & 0.2762 \\
\hline 0.25 & 0.50 & 0.19 & 0.3308 & 1.01 & 0.1574 & 0.35 & 0.2776 & 0.43 & 0.2568 \\
\hline 0.25 & 0.75 & 0.07 & 0.3957 & 2.84 & 0.0467 & 0.11 & 0.3724 & 0.05 & 0.4100 \\
\hline 0.25 & 0.90 & 0.03 & 0.4318 & 0.47 & 0.2471 & 0.22 & 0.3203 & 0.07 & 0.3936 \\
\hline 0.50 & 0.75 & 0.01 & 0.4660 & 0.75 & 0.1935 & 0.07 & 0.3950 & 0.22 & 0.3192 \\
\hline 0.50 & 0.90 & 0.29 & 0.2948 & 0.09 & 0.3848 & 1.54 & 0.1082 & 0.09 & 0.3796 \\
\hline 0.75 & 0.90 & 0.28 & 0.2974 & 0.01 & 0.4644 & 1.48 & 0.1123 & 0.01 & 0.4656 \\
\hline
\end{tabular}

\begin{tabular}{cccccc}
\hline \multicolumn{9}{c}{ metal } & \multicolumn{2}{c}{ other industry } \\
\hline $\mathrm{Q}_{\mathrm{A}}$ & $\mathrm{Q}_{\mathrm{B}}$ & $\mathrm{t}$-stat & $\mathrm{p}$-value & t-stat & p-value \\
\hline 0.1 & 0.25 & 0.01 & 0.4647 & 0.10 & 0.3750 \\
0.1 & 0.50 & 0.00 & 0.4746 & 0.00 & 0.4834 \\
0.1 & 0.75 & 0.01 & 0.4576 & 0.03 & 0.4297 \\
0.1 & 0.90 & 0.05 & 0.4116 & 0.00 & 0.4985 \\
0.25 & 0.50 & 0.04 & 0.4227 & 0.14 & 0.3528 \\
0.25 & 0.75 & 0.00 & 0.4811 & 0.00 & 0.4812 \\
0.25 & 0.90 & 0.04 & 0.4221 & 0.04 & 0.4171 \\
0.50 & 0.75 & 0.11 & 0.3728 & 0.12 & 0.3653 \\
0.50 & 0.90 & 0.11 & 0.3727 & 0.00 & 0.4855 \\
0.75 & 0.90 & 0.04 & 0.4181 & 0.06 & 0.4058 \\
\hline
\end{tabular}




\section{Figure C1}
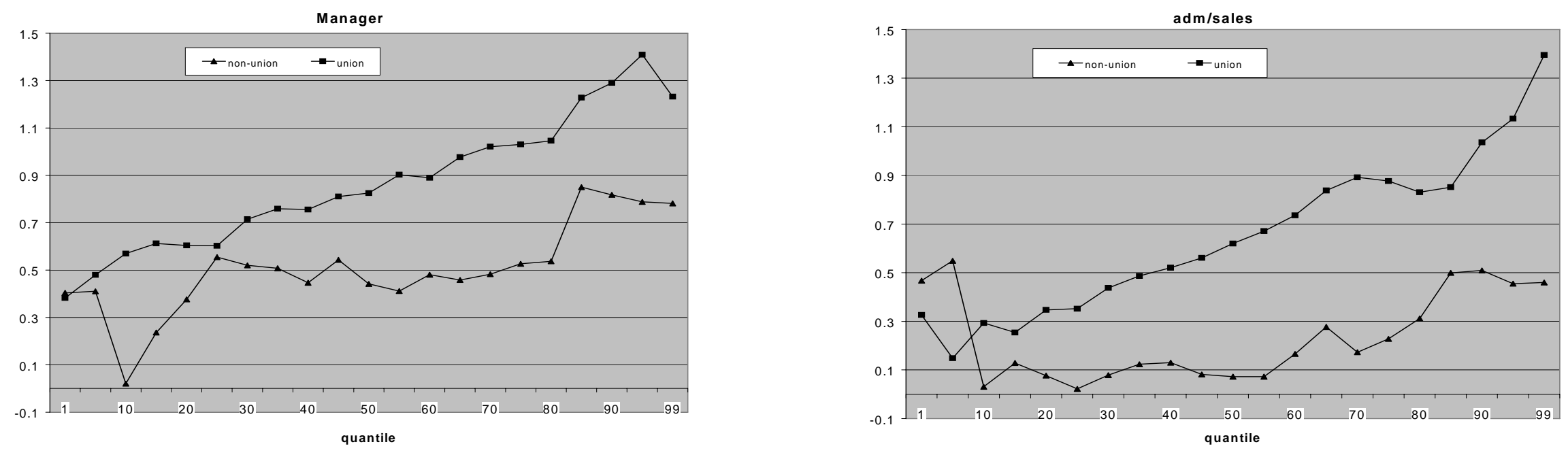

technician/maintenance
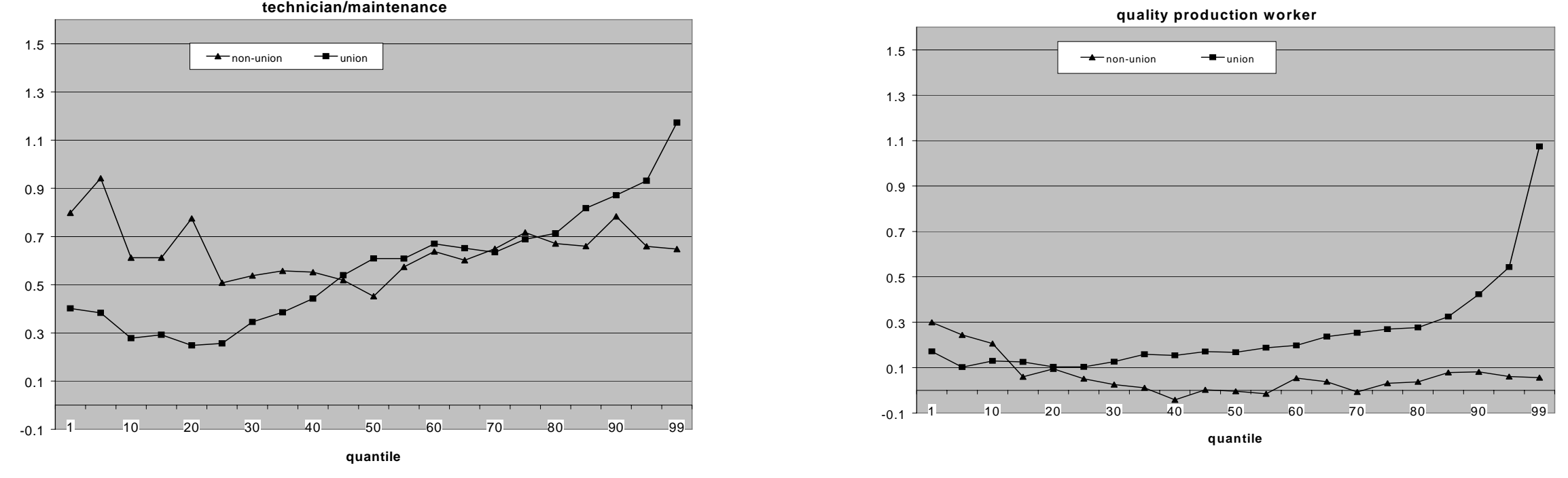
Workers in firms with 40 employees or more

\begin{tabular}{|c|c|c|c|c|c|c|c|c|c|c|c|c|}
\hline \multirow[t]{3}{*}{$\mathrm{n}=528$} & \multicolumn{10}{|c|}{ quantile regressions } & \multicolumn{2}{|c|}{ OLS } \\
\hline & \multicolumn{2}{|c|}{0.1} & \multicolumn{2}{|c|}{0.25} & \multicolumn{2}{|c|}{0.50} & \multicolumn{2}{|c|}{0.75} & \multicolumn{2}{|c|}{0.90} & \multirow[b]{2}{*}{ coef } & \multirow[b]{2}{*}{ pvalue } \\
\hline & coef & pvalue & coef & pvalue & coef & pvalue & coef & pvalue & coef & pvalue & & \\
\hline constant & 10.0154 & $0.000^{\mathrm{d}}$ & 10.0864 & $0.000^{\mathrm{d}}$ & 10.3631 & $0.000^{\mathrm{d}}$ & 10.6268 & $0.000^{\mathrm{d}}$ & 10.5598 & $0.000^{\mathrm{d}}$ & 10.3209 & $0.000^{\mathrm{d}}$ \\
\hline \multicolumn{13}{|l|}{$\begin{array}{l}\text { individual } \\
\text { characteristics }\end{array}$} \\
\hline yrgroup2 & 0.1567 & 0.454 & 0.3140 & $0.070^{\mathrm{b}}$ & 0.2424 & $0.070^{\mathrm{b}}$ & 0.3673 & $0.000^{d}$ & 0.5275 & $0.000^{\mathrm{d}}$ & 0.3513 & $0.013^{\mathrm{c}}$ \\
\hline yrgroup3 & 0.2469 & 0.287 & 0.3971 & $0.041^{\mathrm{c}}$ & 0.4094 & $0.010^{\mathrm{d}}$ & 0.5612 & $0.000^{\mathrm{d}}$ & 0.8206 & $0.000^{\mathrm{d}}$ & 0.5571 & $0.000^{\mathrm{d}}$ \\
\hline Ivorian & 0.0151 & 0.867 & 0.0831 & 0.287 & 0.0047 & 0.964 & -0.1551 & $0.116^{\mathrm{a}}$ & -0.2030 & 0.308 & -0.1086 & $0.150^{\mathrm{a}}$ \\
\hline union density & -0.1276 & 0.307 & -0.1098 & 0.319 & -0.1419 & $0.138^{\mathrm{a}}$ & -0.1353 & 0.236 & -0.1135 & 0.377 & -0.1978 & $0.026^{\mathrm{c}}$ \\
\hline edubasic & -0.0142 & 0.870 & 0.0204 & 0.764 & 0.0516 & 0.460 & 0.0904 & 0.251 & 0.1987 & $0.064^{\mathrm{b}}$ & 0.1262 & $0.102^{\mathrm{a}}$ \\
\hline eduhigh & 0.3362 & $0.004^{d}$ & 0.3818 & $0.001^{\mathrm{d}}$ & 0.4994 & $0.001^{\mathrm{d}}$ & 0.6598 & $0.000^{d}$ & 0.8077 & $0.001^{\mathrm{d}}$ & 0.6918 & $0.000^{\mathrm{d}}$ \\
\hline tenure2 & 0.2184 & 0.076 & 0.1526 & $0.056^{\mathrm{b}}$ & 0.1347 & $0.060^{\mathrm{b}}$ & 0.0163 & 0.865 & -0.0943 & 0.463 & 0.1154 & $0.101^{\mathrm{a}}$ \\
\hline tenure3 & 0.4085 & $0.001^{\mathrm{d}}$ & 0.3583 & $0.000^{\mathrm{d}}$ & 0.2646 & $0.003^{\mathrm{d}}$ & 0.2020 & $0.032^{\mathrm{c}}$ & 0.0779 & 0.556 & 0.2490 & $0.000^{\mathrm{d}}$ \\
\hline $\begin{array}{l}\text { french/leban } \\
\text { occupation }\end{array}$ & 0.0977 & 0.275 & 0.1080 & $0.114^{\mathrm{a}}$ & 0.0788 & 0.281 & 0.0694 & 0.361 & 0.0843 & 0.399 & 0.1321 & $0.048^{\mathrm{c}}$ \\
\hline manager & 0.4634 & $0.001^{\mathrm{d}}$ & 0.5465 & $0.000^{\mathrm{d}}$ & 0.7618 & $0.000^{d}$ & 0.9502 & $0.000^{\mathrm{d}}$ & 1.2093 & $0.000^{\mathrm{d}}$ & 0.7178 & $0.000^{\mathrm{d}}$ \\
\hline $\mathrm{adm} / \mathrm{sales}$ & 0.2504 & $0.020^{\mathrm{c}}$ & 0.4276 & $0.002^{\mathrm{d}}$ & 0.6761 & $0.000^{\mathrm{d}}$ & 0.8310 & $0.000^{\mathrm{d}}$ & 0.8517 & $0.000^{\mathrm{d}}$ & 0.5695 & $0.000^{\mathrm{d}}$ \\
\hline tech/mainten & 0.2489 & $0.094^{\mathrm{b}}$ & 0.3708 & $0.002^{\mathrm{d}}$ & 0.6497 & $0.000^{\mathrm{d}}$ & 0.8059 & $0.000^{\mathrm{d}}$ & 0.9944 & $0.000^{\mathrm{d}}$ & 0.6114 & $0.000^{\mathrm{d}}$ \\
\hline $\begin{array}{l}\text { qualified prod. } \\
\text { industry }\end{array}$ & -0.0097 & 0.903 & $1.1 \mathrm{E}-8$ & 1.000 & 0.0906 & 0.170 & 0.1987 & $0.014^{\mathrm{c}}$ & 0.3678 & $0.001^{\mathrm{d}}$ & 0.1030 & $0.149^{\mathrm{a}}$ \\
\hline food & 0.1237 & 0.612 & 0.0954 & 0.444 & 0.3038 & $0.007^{\mathrm{d}}$ & 0.3610 & $0.001^{\mathrm{d}}$ & 0.4675 & $0.003^{\mathrm{d}}$ & 0.2757 & $0.004^{\mathrm{d}}$ \\
\hline wood & 0.3911 & $0.065^{b}$ & 0.1847 & $0.076^{\mathrm{b}}$ & 0.1806 & $0.098^{\mathrm{b}}$ & 0.1880 & $0.048^{c}$ & 0.3234 & $0.019^{\mathrm{c}}$ & 0.2250 & $0.020^{\mathrm{c}}$ \\
\hline metal & 0.4459 & $0.047^{\mathrm{c}}$ & 0.1906 & $0.087^{\mathrm{b}}$ & 0.2647 & $0.013^{\mathrm{c}}$ & 0.1736 & $0.088^{\mathrm{b}}$ & 0.3121 & $0.009^{\mathrm{d}}$ & 0.2387 & $0.014^{\mathrm{c}}$ \\
\hline other/no stated & 0.8005 & $0.004^{\mathrm{d}}$ & 0.3887 & $0.023^{\mathrm{c}}$ & 0.4758 & $0.001^{\mathrm{d}}$ & 0.3558 & $0.001^{\mathrm{d}}$ & 0.3684 & $0.064^{\mathrm{b}}$ & 0.4173 & $0.002^{\mathrm{d}}$ \\
\hline value added & $6.5 \mathrm{E}-9$ & 0.265 & $1.1 \mathrm{E}-8$ & $0.007^{\mathrm{d}}$ & $8.0 \mathrm{E}-9$ & $0.015^{\mathrm{c}}$ & $8.4 \mathrm{E}-9$ & $0.088^{\mathrm{b}}$ & $1.4 \mathrm{E}-8$ & $0.074^{\mathrm{b}}$ & $1.0 \mathrm{E}-8$ & $0.006^{\mathrm{d}}$ \\
\hline year dummy & -0.0311 & 0.775 & 0.1871 & $0.016^{\mathrm{c}}$ & 0.1731 & $0.025^{\mathrm{c}}$ & 0.1920 & $0.011^{\mathrm{c}}$ & 0.1495 & 0.288 & 0.1969 & $0.005^{\mathrm{d}}$ \\
\hline \multicolumn{13}{|c|}{ Workers in firms with less than 40 employees } \\
\hline \multirow[t]{3}{*}{$\mathrm{n}=363$} & \multicolumn{10}{|c|}{ quantile regressions } & \multicolumn{2}{|c|}{ OLS } \\
\hline & \multicolumn{2}{|c|}{0.1} & \multicolumn{2}{|c|}{0.25} & \multicolumn{2}{|c|}{0.50} & & & & & & \\
\hline & coef & pvalue & coef & pvalue & coef & pvalue & coef & pvalue & coef & pvalue & coef & pvalue \\
\hline constant & $9 . .3356$ & $0.000^{\mathrm{d}}$ & 9.8308 & $0.000^{\mathrm{d}}$ & 10.040 & $0.000^{\mathrm{d}}$ & 10.5103 & $0.000^{\mathrm{d}}$ & 10.7841 & $0.000^{\mathrm{d}}$ & 10.0582 & $0.000^{\mathrm{d}}$ \\
\hline $\begin{array}{l}\text { individual } \\
\text { characteristics }\end{array}$ & & & & & & & & & & & & \\
\hline yrgroup2 & 0.3755 & $0.056^{\mathrm{b}}$ & 0.1264 & 0.152 & 0.2499 & $0.006^{\mathrm{d}}$ & 0.1821 & $0.049^{c}$ & 0.1310 & 0.204 & 0.1859 & $0.035^{\mathrm{c}}$ \\
\hline yrgroup3 & 0.5561 & $0.009^{\mathrm{d}}$ & 0.3556 & $0.015^{\mathrm{c}}$ & 0.3817 & $0.001^{\mathrm{d}}$ & 0.2750 & $0.028^{\mathrm{c}}$ & 0.0888 & 0.531 & 0.3400 & $0.006^{\mathrm{d}}$ \\
\hline Ivorian & 0.0986 & 0.433 & 0.1473 & $0.103^{\mathrm{a}}$ & 0.1318 & $0.115^{\mathrm{a}}$ & -0.0736 & 0.399 & -0.2961 & $0.052^{\mathrm{b}}$ & 0.0105 & 0.883 \\
\hline union density & 0.2637 & $0.022^{c}$ & 0.2264 & $0.010^{\mathrm{d}}$ & 0.0816 & 0.329 & 0.2633 & $0.040^{\mathrm{c}}$ & 0.3698 & $0.052^{\mathrm{b}}$ & 0.2994 & $0.001^{\mathrm{d}}$ \\
\hline edubasic & $-4.5 \mathrm{E}-8$ & 1.000 & -0.0015 & 0.985 & -0.0192 & 0.759 & -0.0542 & 0.403 & -0.0422 & 0.668 & 0.0197 & 0.798 \\
\hline eduhigh & -0.0458 & 0.775 & 0.1510 & 0.383 & 0.3850 & $0.061^{\mathrm{b}}$ & 0.6730 & $0.023^{\mathrm{c}}$ & 0.6452 & $0.119^{\mathrm{a}}$ & 0.4909 & $0.000^{\mathrm{d}}$ \\
\hline tenure2 & 0.1698 & 0.178 & 0.1706 & $0.084^{\mathrm{b}}$ & 0.1745 & $0.031^{\mathrm{c}}$ & 0.1401 & $0.121^{\mathrm{a}}$ & 0.0489 & 0.669 & 0.1373 & $0.078^{\mathrm{b}}$ \\
\hline tenure3 & 0.1506 & 0.199 & 0.1586 & 0.178 & 0.2133 & $0.017^{\mathrm{c}}$ & 0.1737 & $0.110^{\mathrm{a}}$ & 0.2031 & 0.194 & 0.2571 & $0.009^{\mathrm{d}}$ \\
\hline $\begin{array}{l}\text { french/leban } \\
\text { occupation }\end{array}$ & 0.2769 & $0.008^{\mathrm{d}}$ & 0.2855 & $0.000^{\mathrm{d}}$ & 0.3037 & $0.000^{\mathrm{d}}$ & 0.2781 & $0.002^{\mathrm{d}}$ & 0.1882 & $0.133^{\mathrm{a}}$ & 0.2813 & $0.001^{\mathrm{d}}$ \\
\hline manager & 0.8511 & $0.000^{d}$ & 0.7674 & $0.000^{\mathrm{d}}$ & 0.7216 & $0.000^{\mathrm{d}}$ & 0.8598 & $0.003^{\mathrm{d}}$ & 0.1603 & $0.001^{\mathrm{d}}$ & 0.8440 & $0.000^{\mathrm{d}}$ \\
\hline $\mathrm{adm} / \mathrm{sales}$ & 0.0439 & 0.766 & 0.1588 & 0.209 & 0.2092 & 0.154 & 0.4511 & $0.053^{\mathrm{b}}$ & 0.8284 & $0.006^{\mathrm{d}}$ & 0.4462 & $0.000^{\mathrm{d}}$ \\
\hline tech/mainten & 0.6707 & $0.000^{\mathrm{d}}$ & 0.4749 & $0.000^{\mathrm{d}}$ & 0.3628 & $0.031^{\mathrm{c}}$ & 0.7276 & $0.003^{\mathrm{d}}$ & 0.6454 & $0.008^{\mathrm{d}}$ & 0.5545 & $0.000^{\mathrm{d}}$ \\
\hline $\begin{array}{l}\text { qualified prod. } \\
\text { industry }\end{array}$ & 0.3495 & $0.001^{\mathrm{d}}$ & 0.1921 & $0.026^{\mathrm{c}}$ & 0.1573 & $0.028^{c}$ & 0.1080 & $0.113^{\mathrm{a}}$ & 0.1563 & $0.112^{\mathrm{a}}$ & 0.1533 & $0.041^{\mathrm{c}}$ \\
\hline food & 0.2118 & 0.178 & 0.1393 & 0.270 & 0.2102 & $0.060^{\mathrm{b}}$ & 0.1056 & 0.300 & 0.1830 & $0.128^{\mathrm{a}}$ & 0.0831 & 0.469 \\
\hline wood & -0.1287 & 0.428 & -0.0320 & 0.810 & 0.1355 & 0.217 & 0.0766 & 0.451 & 0.2333 & $0.077^{\mathrm{b}}$ & 0.0102 & 0.925 \\
\hline metal & 0.2407 & $0.076^{\mathrm{b}}$ & 0.1751 & $0.131^{\mathrm{a}}$ & 0.2921 & $0.011^{\mathrm{c}}$ & 0.1963 & $0.127^{\mathrm{a}}$ & 0.7059 & $0.009^{\mathrm{d}}$ & 0.3335 & $0.005^{\mathrm{d}}$ \\
\hline other/no stated & -0.2032 & 0.153 & -0.2362 & $0.028^{\mathrm{c}}$ & -0.2142 & $0.039^{\mathrm{c}}$ & -0.2480 & $0.146^{\mathrm{a}}$ & -0.1251 & 0.571 & -0.1693 & 0.198 \\
\hline value added & $2.4 \mathrm{E}-8$ & $0.000^{\mathrm{d}}$ & $1.6 \mathrm{E}-8$ & $0.000^{\mathrm{d}}$ & $9.3 \mathrm{E}-9$ & $0.008^{\mathrm{d}}$ & $7.6 \mathrm{E}-9$ & 0.176 & 9.8E-9 & 0.176 & $1.4 \mathrm{E}-8$ & $0.000^{\mathrm{d}}$ \\
\hline year dummy & 0.2623 & $0.003^{\mathrm{d}}$ & 0.2229 & $0.009^{\mathrm{d}}$ & 0.1835 & $0.008^{\mathrm{d}}$ & 0.2325 & $0.012^{\mathrm{c}}$ & 0.3319 & $0.025^{\mathrm{c}}$ & 0.2636 & $0.000^{\mathrm{d}}$ \\
\hline
\end{tabular}

Note: a-significance at the $15 \%$ level; b-10\%; c-5\%; d- $1 \%$. 


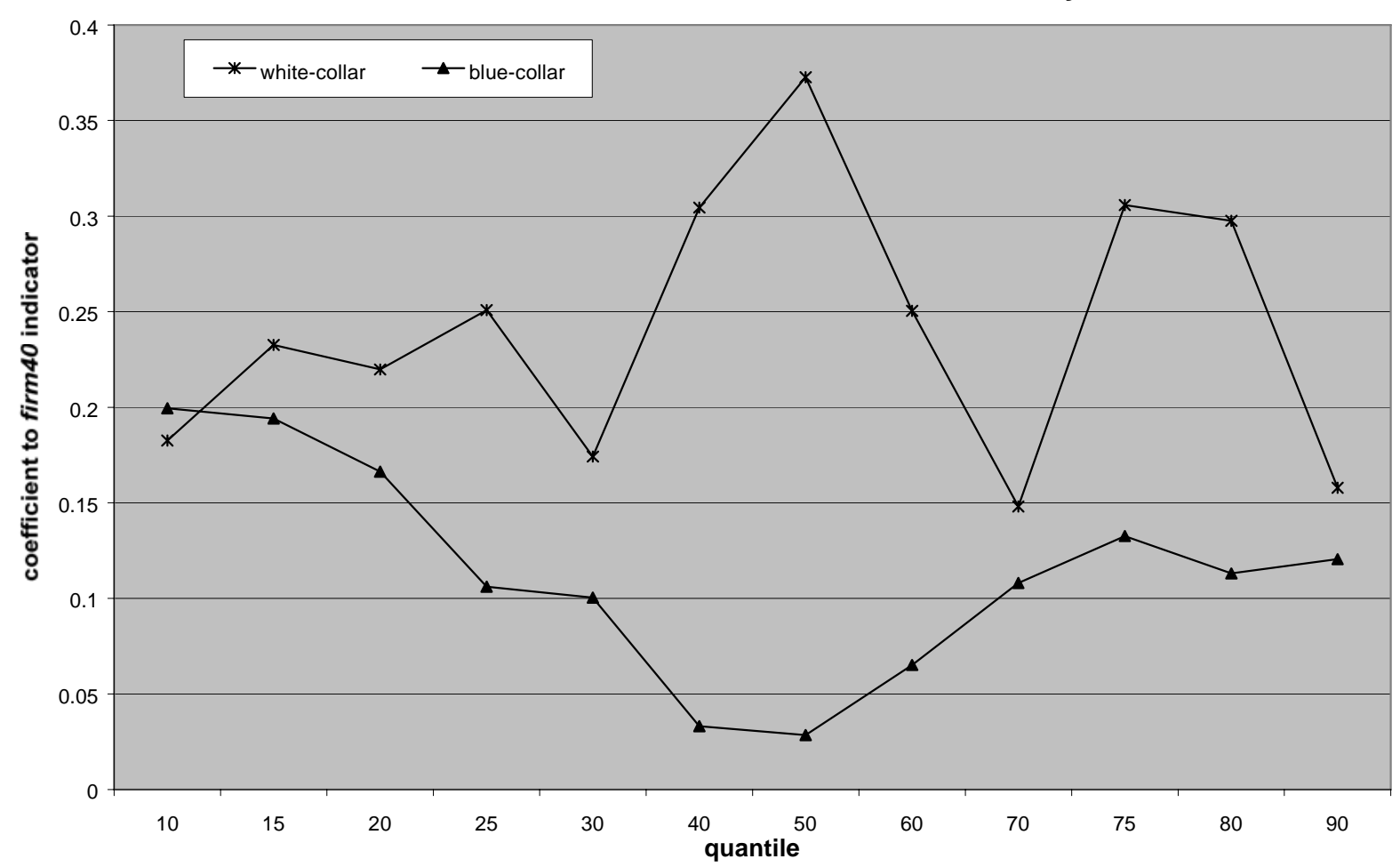




\section{Appendix E, Literature overview of studies of the labor market in Côte d'Ivoire}

\begin{tabular}{|c|c|c|c|c|c|c|c|c|}
\hline \multirow[t]{2}{*}{ Author(s) } & \multirow[t]{2}{*}{ Year } & \multirow[t]{2}{*}{ Purpose of study } & \multirow[t]{2}{*}{ Data } & \multirow{2}{*}{$\begin{array}{l}\text { Dependent } \\
\text { variable }\end{array}$} & \multirow[t]{2}{*}{ Method } & \multicolumn{2}{|c|}{ Coefficient of key variables } & \multirow{2}{*}{$\begin{array}{l}\text { Significant } \\
* *=5 \% \\
*=10 \%\end{array}$} \\
\hline & & & & & & Variable & Coeff & \\
\hline Grootaert, C. & 1990 & $\begin{array}{l}\text { To compare graduates of the formal } \\
\text { vocational and technical education } \\
\text { system in Côte d'Ivoire with those of } \\
\text { informal apprenticeships explicitly } \\
\text { considering the structure of the labor } \\
\text { market }\end{array}$ & $\begin{array}{l}\text { CILSS } \\
1985\end{array}$ & $\begin{array}{l}\text { log } \\
\text { monthly } \\
\text { earnings }\end{array}$ & $\begin{array}{l}\text { Heckman's } \\
\text { selection model }\end{array}$ & $\begin{array}{l}\text { yrs primary edu } \\
\text { yrs second. edu } \\
\text { yrs higher edu } \\
\text { yrs current job exp } \\
\text { yrs current job exp, sq } \\
\text { diplomas (different types) } \\
\text { rural dummy } \\
\text { non-ivorien dummy } \\
\text { female dummy }\end{array}$ & $\begin{array}{l}0.031 \\
0.127 \\
0.130 \\
0.084 \\
-0.0015 \\
\text { varies } \\
-0.289 \\
-0.042 \\
0.079\end{array}$ & $\begin{array}{l}* * \\
* * \\
* * \\
* * \\
\text { none } \\
* *\end{array}$ \\
\hline $\begin{array}{l}\text { Komenan, A.G. and } \\
\text { Gootaert, C. }\end{array}$ & 1990 & $\begin{array}{l}\text { To analyze pay differences between } \\
\text { teachers and other wage earners in } \\
\text { Côte d'Ivoire controling for various } \\
\text { personal characteristics }\end{array}$ & $\begin{array}{l}\text { CILSS } \\
1985\end{array}$ & $\begin{array}{l}\log \\
\text { monthly } \\
\text { total wages }\end{array}$ & $\begin{array}{l}\text { Wage regressions } \\
\text { (also on different } \\
\text { sub-groups - not } \\
\text { reported here) }\end{array}$ & $\begin{array}{l}\text { yrs of schooling } \\
\text { diploma } \\
\text { experience } \\
\text { experience, sq } \\
\text { log monthly hours worked } \\
\text { government dummy } \\
\text { female } \\
\text { ivorien } \\
\text { abidjan dummy } \\
\text { teacher dummy }\end{array}$ & $\begin{array}{l}0.1678 \\
0.1228 \\
0.1151 \\
-0.002 \\
0.1302 \\
-0.0224 \\
-0.1782 \\
0.1545 \\
-0.092 \\
0.008\end{array}$ & $\begin{array}{l}* * \\
* * \\
* * \\
* * \\
*\end{array}$ \\
\hline Hoddinott, J. & 1996 & $\begin{array}{l}\text { To analyze the relationship between } \\
\text { wages and unemployment; with focus } \\
\text { on the urban labor market }\end{array}$ & $\begin{array}{l}\text { CILSS } \\
1985,1986, \\
1987, \\
\text { pooled } \\
\text { sample }\end{array}$ & $\begin{array}{l}\text { log hourly } \\
\text { nominal } \\
\text { wages }\end{array}$ & $\begin{array}{l}2 \text { stage method; a } \\
\text { logit for } \\
\text { participating in } \\
\text { the labor market }\end{array}$ & $\begin{array}{l}\text { lagged rate of unempl. } \\
\text { potential exp } \\
\text { potential exp, sq } \\
\text { completed grades } \\
\text { head of household } \\
\text { married } \\
\text { non-ivorien } \\
\text { occupation } \\
\quad \text { service worker } \\
\text { skilled worker } \\
\text { teacher/principal } \\
\text { white collar } \\
\text { other tech/prof } \\
\text { location } \\
\text { abidjan or bouake } \\
\text { eastern region town } \\
\text { western region town }\end{array}$ & $\begin{array}{l}-0.7492 \\
0.0677 \\
-0.0026 \\
0.1283 \\
-0.1002 \\
0.1094 \\
-0.0875 \\
\\
-0.1216 \\
-0.0256 \\
0.5723 \\
0.3420 \\
0.0903 \\
\\
0.1190 \\
-0.3127 \\
-0.3908\end{array}$ & $\begin{array}{l}* \\
* \\
* * \\
\\
* * \\
* *\end{array}$ \\
\hline
\end{tabular}




\section{Appendix E, Literature overview of studies of the labor market in Côte d'Ivoire}

\begin{tabular}{|c|c|c|c|c|c|c|c|c|}
\hline & & & & & & \multicolumn{2}{|c|}{ Coefficient of key variables } & \\
\hline $\begin{array}{l}\text { Vijverberg, W.P.M. } \\
\text { and Van der Gaag, J. }\end{array}$ & 1991 & $\begin{array}{l}\text { To challenge the usual assumption of } \\
\text { a homogenous wage sector }\end{array}$ & $\begin{array}{l}\text { CILSS } \\
1985\end{array}$ & $\begin{array}{l}\text { log hourly } \\
\text { wage rate } \\
\text { (including } \\
\text { the cash } \\
\text { value of in- } \\
\text { kind } \\
\text { income }\end{array}$ & $\begin{array}{l}\text { ML two-stage } \\
\text { method with both } \\
\text { OLS and GLS in } \\
\text { the structural } \\
\text { model (GLS } \\
\text { reported here) }\end{array}$ & $\begin{array}{l}\text { yrs schooling } \\
\text { yrs schooling, sq/100 } \\
\text { experience in current job } \\
\text { exp. current job, sq/100 } \\
\text { general experience } \\
\text { general experience, sq/100 } \\
\text { female dummy } \\
\text { non-ivorien }\end{array}$ & $\begin{array}{l}0.077 \\
0.240 \\
0.106 \\
-0.214 \\
0.048 \\
-0.085 \\
0.420 \\
-0.089\end{array}$ & $\begin{array}{l}* * \\
* * \\
*\end{array}$ \\
\hline $\begin{array}{l}\text { Vijverberg, W.P.M. } \\
\text { and Van der Gaag, J. }\end{array}$ & 1988 & $\begin{array}{l}\text { To contribute to the Mincerian } \\
\text { returns to education literature and } \\
\text { focus on public-private sector } \\
\text { differentials }\end{array}$ & $\begin{array}{l}\text { CILSS } \\
1985\end{array}$ & $\begin{array}{l}\text { log wages } \\
\text { for public } \\
\text { and private } \\
\text { sector } \\
\text { workers } \\
\text { respectivel } \\
\text { y }\end{array}$ & $\begin{array}{l}\text { Full information } \\
\text { maximum } \\
\text { likelihood } \\
\text { (FIML) }\end{array}$ & $\begin{array}{l}\text { Public sector: } \\
\text { yrs elem sch } \\
\text { yrs junior high 1 } \\
\text { diploma elem sch } \\
\text { diploma junior high } 1 \\
\text { higher diploma } \\
\text { current job experience } \\
\text { curr job exp, sq*100 } \\
\text { non-ivorien } \\
\text { female } \\
\text { RRR } \\
\text { Private sector: } \\
\text { yrs elem sch } \\
\text { yrs junior high 1 } \\
\text { diploma elem sch } \\
\text { diploma junior high } 1 \\
\text { higher diploma } \\
\text { current job experience } \\
\text { curr job exp, sq*100 } \\
\text { non-ivorien } \\
\text { female } \\
\text { RRR }\end{array}$ & $\begin{array}{l}0.035 \\
0.205 \\
0.801 \\
0.424 \\
0.621 \\
0.087 \\
-0.868 \\
-- \\
-0.125 \\
0.108 \\
\\
0.018 \\
0.012 \\
0.395 \\
0.617 \\
0.221 \\
0.116 \\
-2.258 \\
0.285 \\
0.141 \\
0.147\end{array}$ & $\begin{array}{l}* * \\
* * \\
* * \\
* * \\
* *\end{array}$ \\
\hline
\end{tabular}




\section{Appendix E, Literature overview of studies of the labor market in Côte d'Ivoire}

\begin{tabular}{|c|c|c|c|c|c|c|c|c|}
\hline & & & & & & \multicolumn{2}{|c|}{ Coefficient of key variables } & \\
\hline Vijverberg, W.P.M. & 1992 & $\begin{array}{l}\text { To seek answers to the questions: Do } \\
\text { women in the labor market enjoy the } \\
\text { same returns to their human capital } \\
\text { investments as men do? Is the } \\
\text { different treatment of women in the } \\
\text { labor market a cause for the lower } \\
\text { educational attainment so often } \\
\text { observed among women in the third } \\
\text { world? }\end{array}$ & $\begin{array}{l}\text { Pooled } \\
\text { CILSS } \\
1985,1986, \\
1987\end{array}$ & $\begin{array}{l}\text { log hourly } \\
\text { earnings in } \\
\text { wage } \\
\text { employmen } \\
t\end{array}$ & $\begin{array}{l}\text { Two-stage } \\
\text { estimation } \\
\text { procedure (self- } \\
\text { selection model } \\
\text { with two decision } \\
\text { variables: where } \\
\text { to live and what } \\
\text { work (if any) to } \\
\text { choose. }\end{array}$ & $\begin{array}{l}\text { Abidjan, men: } \\
\text { yrs elem school } \\
\text { yrs junior high } \\
\text { yrs senior high } \\
\text { yrs university } \\
\text { occupational exp } \\
\text { occup exp, sq/100 } \\
\text { prior exp } \\
\text { prior exp, sq/100 } \\
\text { non-ivorien } \\
\text { Abidjan, women: } \\
\text { yrs elem school } \\
\text { yrs junior high } \\
\text { yrs senior high } \\
\text { yrs university } \\
\text { occupational exp } \\
\text { occup exp, sq/100 } \\
\text { prior exp } \\
\text { prior exp, sq/100 } \\
\text { non-ivorien }\end{array}$ & $\begin{array}{l}0.099 \\
0.121 \\
0.162 \\
0.196 \\
0.083 \\
-0.121 \\
0.026 \\
-0.005 \\
-0.110 \\
\\
0.020 \\
0.286 \\
0.230 \\
0.246 \\
0.102 \\
-0.158 \\
0.049 \\
-0.057 \\
0.080\end{array}$ & $\begin{array}{l}* * \\
* * \\
* * \\
* * \\
* * \\
* * \\
* * \\
* *\end{array}$ \\
\hline Vijverberg, W.P.M. & 1989 & $\begin{array}{l}\text { To analyze whether migrants are } \\
\text { more productive workers than } \\
\text { nonmigrants }\end{array}$ & $\begin{array}{l}\text { CILSS } \\
1985-1986 \\
\text { panel data }\end{array}$ & $\begin{array}{l}\text { log hourly } \\
\text { wages }\end{array}$ & $\begin{array}{l}\text { Self-selection } \\
\text { model with a } \\
\text { choice of activity }\end{array}$ & $\begin{array}{l}\text { yrs elem school } \\
\text { yrs junior high school } \\
\text { yrs senior high school } \\
\text { yrs university } \\
\text { diploma } \\
\quad \text { elememtary } \\
\quad \text { junior high } \\
\quad \text { beyond junior high } \\
\text { RRR } \\
\text { yrs occup. specific exp } \\
\text { yrs squared*100 } \\
\text { yrs general exp } \\
\text { yrs squared*100 } \\
\text { abidjan dummy } \\
\text { other urban dummy } \\
\text { non-ivorien } \\
\text { female }\end{array}$ & $\begin{array}{l}0.104 \\
0.102 \\
-0.010 \\
0.223 \\
\\
0.402 \\
0.608 \\
0.642 \\
0.159 \\
0.106 \\
-0.217 \\
0.075 \\
-0.078 \\
0.160 \\
0.114 \\
-0.033 \\
-0.056\end{array}$ & $\begin{array}{l}* * \\
* * \\
* * \\
* * \\
* * \\
* * \\
* * \\
* * \\
*\end{array}$ \\
\hline
\end{tabular}


Appendix E, Literature overview of studies of the labor market in Côte d'Ivoire

\begin{tabular}{|c|c|c|c|c|c|c|c|c|}
\hline & & & & & & \multicolumn{2}{|c|}{ Coefficient of key variables } & \\
\hline $\begin{array}{l}\text { Vijverberg, W.P.M. } \\
\text { and Van der Gaag, J. }\end{array}$ & 1989 & $\begin{array}{l}\text { To investigate wage determinants } \\
\text { using the Mincerian framework; with } \\
\text { a special eye on the role of credentials }\end{array}$ & $\begin{array}{l}\text { CILSS } \\
1985\end{array}$ & $\begin{array}{l}\text { log hourly } \\
\text { wage }\end{array}$ & OLS & $\begin{array}{l}\text { yrs elem school } \\
\text { yrs junior high school } \\
\text { yrs senior high school } \\
\text { yrs university } \\
\text { diploma } \\
\quad \text { elememtary } \\
\quad \text { junior high } \\
\quad \text { beyond junior high } \\
\text { RRR } \\
\text { yrs occup. specific exp } \\
\text { yrs squared*1000 } \\
\text { yrs general exp } \\
\text { yrs squared*1000 } \\
\text { non-ivorien } \\
\text { female }\end{array}$ & $\begin{array}{l}0.023 \\
0.088 \\
-0.032 \\
0.208 \\
\\
0.494 \\
0.594 \\
0.536 \\
0.113 \\
0.107 \\
-1.909 \\
0.026 \\
0.020 \\
-0.117 \\
0.011\end{array}$ & $\begin{array}{l}* * \\
* * \\
* \\
* \\
* * \\
* * \\
* * \\
* *\end{array}$ \\
\hline
\end{tabular}


Hazel M. Vargas

L:\VERNER \Labor Markets \QuantileRPED-3.doc

01/28/00 5:44 PM 